\title{
Mycosphere Essay 11: Fungi of Pycnoporus: morphological and molecular identification, worldwide distribution and biotechnological potential
}

\section{Téllez-Téllez $\mathbf{M}^{2}$, Villegas $\mathbf{E}^{3}$, Rodríguez $\mathbf{A}^{3}$, Acosta-Urdapilleta $\mathbf{M L}^{2}$, O’Donovan A ${ }^{4}$, Díaz-Godínez $\mathbf{G}^{1}$}

\author{
${ }^{1}$ Centro de Investigación en Ciencias Biológicas, Universidad Autónoma de Tlaxcala, Tlaxcala, México. \\ diazgdo@hotmail.com \\ ${ }^{2}$ Centro de Investigaciones Biológicas, Universidad Autónoma del Estado de Morelos, Cuernavaca Morelos, México. \\ maura.tellez@uame.mx,urdapilletal@yahoo.com \\ ${ }^{3}$ Centro de Investigación en Biotecnología, Universidad Autónoma del Estado de Morelos, Cuernavaca Morelos. \\ elbav@uaem.mx, alexis.rodriguez@uaem.mx \\ ${ }^{4}$ Molecular Glycobiotechnology Group, Department of Biochemistry, School of Natural Sciences, National University \\ of Ireland Galway, Galway, Ireland
}

Téllez-Téllez M, Villegas E, Rodríguez A, Acosta-Urdapilleta ML, Díaz-Godínez G 2016 Mycosphere Essay 11: Fungi of Pycnoporus genus: morphological and molecular identification, worldwide distribution and biotechnological potential. Mycosphere 7(10), 1500-1525, Doi $10.5943 / \mathrm{mycosphere} / \mathrm{si} / 3 \mathrm{~b} / 3$

\begin{abstract}
Fungi of the Pycnoporus are efficient degraders of lignocellulosic materials, so they are classified as white-rot fungi. A distinctive feature is its color ranging from orange to bright red, attributed to cinnabarin, cinnabarinic acid and tramesanguin mainly, compounds to which have been attributed some biological activities. This review updates the reports on morphological characteristics, the distribution of species of Pycnoporus, and the advantages of molecular techniques in species identification. Furthermore, the potential biotechnological applications of these fungi are mentioned with a focus on insecticidal and antibacterial activities. In addition, the production of hydrolytic enzymes including cellulases, hemicellulases, pectinases are discussed as well as phenoloxidases such as laccases and their participation in the degradation of agro-industrial waste.
\end{abstract}

Keywords - Biotechnological applications - Pycnoporus sanguineus - Pycnoporus cinnabarinus taxonomy - molecular identification

\section{Introduction}

Correct identification of fungi is of great importance. A huge number of fungal species have been described, but even taxonomists are kept busy with the recognition and description of new species and taxa. Therefore, fungal species identification based on morphological characteristics, origin and molecular biology approaches has been limited in some countries and for unskilled persons, it can be a challenge (Guarro et al. 1999). The most important characteristics used in general on the identification of fungi are: 1) Shape of fruiting body, 2) Color of each of the parts of the fruiting body, including internal (meat) and the underground part, 3) Some structures or characteristics of the fruiting body such as: flakes, warts, hairs, spines, pores, stretch marks, 
viscosity, and meatiness, among others, 4) Change in color when manipulated or cut anywhere in the fruiting body, 5) Presence or absence of a milky juice or latex when cut, the latex color should be checked before and after its exposure to air, 6) Smell of fungus (mainly meat), 7) Flavor of the meat, 8) Color of the mass spore and 9) The identity or type of host on which the fruiting body is located (Guzmán 1979). To date, the description and exploration of the diversity of Pycnoporus has been based primarily on the morphological similarity of the specimens referred to with classified specimens in international collections, even though the identification remains a challenge due to the high variability of morphological characteristics during growth. Morphological characteristics of young specimen vary depending on the fruiting body age, kind of wood where they grow, and environmental factorssuch as, temperature, humidity and/or light.

\section{General description of Pycnoporus genus}

The genus Pycnoporus is a cosmopolitan group of white rot fungi, belonging to the phylum Basidiomycota, Agaricomycetes class, Polyporaceos order (Ryvarden 1978, Hibbett et al. 2007). It is related with the genus Trametes, morphologically it is similar in all characteristics except for the bright red-orange color of their basidiocarps (Ryvarden 1991, Ryvarden \& Gilbertson 1994). The Pycnoporus fungi are heterothallic homobasidiomycetes with a tetrapolar mating system (Nobles \& Frew 1962). Pycnoporus fruiting body tends to show the greatest morphological variation, such as size, shape, color, surface texture and consistency, hyphal system, pores, tubes, and macrochemical reactions, for instance, color changes when sample is mistreated, dry or exposed to 5\% KOH, Melzer solution and phenol (Cifuentes et al. 1986, Gilbertson \& Ryvarden 1986). This genus has annual fruiting, and characteristics include smooth pileus, sessile and coriaceous, shelf shaped halfmoon and sometimes faintly marked concentric zones or not. In mature specimens this surface is a whitish or silvery colour (Guzmán 2003). The underside has isodiametric pores ranging in size from small to medium. The context is of the same color as the pileus, and is thin to moderately thick. This genus is characterized by a dimitic or trimitic hyphal system with generative hyphae of thin walls, hyalines and septate, tortuously united with skeletal hyphae of thick walls. Skeletal hyphae present with clear pinkish coloring in preparations. Spores are cylindrical, and hyalines have thin walls, and are smooth and amyloid. Another technique used to verify the identity of the species involves cultivation of different spores. If binding is detected between two strains, then they are considered identical and if not they are different species (Deacon 2013). Table 1 shows the nine Pycnoporus species and their synonymous for the same taxon reported in the Index Fungorum "virtual page, which is an international project to index all scientific names in the Fungi kingdom, it is comparable to International Plant Names Index" (Ulloa \& Hanlin 2006).

Historically, four species were differentiated based on their morphology (basidiocarp shape and size of their pores) and their distribution area (Nobles \& Frew 1962, Ryvarden \& Johansen 1980), although are very similar, there is a high degree of difficulty to identify wild or cultivated specimens (Lesage-Meessen et al. 2011). For Pycnoporus sanguineus, Pycnoporus cinnabarinus, Pycnoporus coccineus and Pycnoporus puniceus the following taxonomic data have been descrybed, and in Table 2 the main basidiocarp morphological differences among them are pointed out.

\section{Pycnoporus sanguineus (L.) Murril}

Annual basidiocarp, pileus shortly and sessile or sometimes overlapping, solitary to gregarious habitat, leathery, coriaceous to corky consistency, with a size 30-30 $\times 22-30 \times 5-10$ $\mathrm{mm}$, diameter, width and thickness respectively. Semicircular pileus of dimidiate, flabelliforme, bright orange red when young and only reddish orange when ripe, velutinous surface to glabrous, zoned; acute margin, from smooth to wavy thin, sterile. Hymenophore poroide, color reddish orange; pores 4-6 per mm, circular tubes concolor to hymenophore, some specimens are concolor to the pileus, up to $1 \mathrm{~mm}$ deep, corky consistency to floccose (Fig. 1). It grows on dead wood, always sunny places and causes white rot. Macro-chemical reactions occur by adding $5 \% \mathrm{KOH}$ resulting in a quick colour change to black in all its parts, but upon drying becomes greenish brown, so it gives a false xanthochromia reaction. 
Table 1 Names of species of genus Pycnoporus.

\begin{tabular}{|c|c|c|}
\hline \multicolumn{2}{|c|}{ Pycnoporus specie } & \multirow{2}{*}{$\begin{array}{l}\text { Synonymous } \\
\text { Pycnoporus coccineus } \text { (Fr.) Bondartsev \& Singer } \\
\text { (1941) }\end{array}$} \\
\hline 1 & $\begin{array}{l}\text { Pycnoporus cinnabarinus (Jacq.) P. Karst } \\
\text { (1881) }\end{array}$ & \\
\hline 2 & Pycnoporus sanguineus (L.) Murril (1904) & $\begin{array}{l}\text { Boletus ruber Lam., (1783), Boletus sanguineus L., } \\
\text { (1763), Coriolus sanguineus (L.) G. Cunn., (1949), } \\
\text { Fabisporus sanguineus (L.) Zmitr., (2001), } \\
\text { Microporus sanguineus (L.) Pat., (1900), Polyporus } \\
\text { sanguineus (L.)Fr., (1821), Polystictus sanguineus } \\
\text { (L.) G. Mey., (1818), Trametes cinnabarina var. } \\
\text { sanguinea (L.) Pilát, (1936), Trametes sanguinea } \\
\text { (L.)Imazeki, (1943), Trametes sanguinea } \\
\text { (L.)Lloyd, (1924). }\end{array}$ \\
\hline 3 & $\begin{array}{l}\text { Pycnoporus coccineus (Fr.) Bondartsev \& } \\
\text { Singer (1941) }\end{array}$ & $\begin{array}{l}\text { Polyporus coccineus } \text { Fr. (1855) } \\
\text { Fomes coccineus } \text { (Fr.) Sacc. (1888) } \\
\text { Scindalma coccineus } \text { (Fr.) Kuntze (1898) } \\
\text { Polystictus coccineus (Fr.) Lloyd (1916) }\end{array}$ \\
\hline 4 & Pycnoporus puniceus (Fr.) Ryvarden (1972) & Trametes punicea Fr. (1851) \\
\hline 5 & Pycnoporus annosus (Fr.) Karst (1898) & Heterobasidium annosum (Fr) Bref. (1888) \\
\hline 6 & Pycnoporus epilobii (P. Karst) P. Karst (1889) & Datronia steroids (Fr.) Ryvarden (1967) \\
\hline 7 & Pycnoporus mimicus P. Karst (1906) & $\begin{array}{l}\text { Fomitopsis cajanderi (P. Karst) Kotl \& Pouzar } \\
\text { (1957) }\end{array}$ \\
\hline 8 & Pycnoporus palibini P. Karst (1911) & \\
\hline 9 & Pycnoporus serialis (Fr.) P. Karst (1889) & Antrodia serialis (Fr) Donk (1966) \\
\hline
\end{tabular}

Index Fungorum (www.indexfungorum.org).

Microscopic data: trimitic hyphal system, cylindrical spores of 5-6 $62-3 \mu \mathrm{m}$, smooth, hyaline, non-amyloid, thin-walled (Table 2). Remarks: This species is characterized by sessile basidiocarps, dimidiate and smooth, with characteristic color of bright reddish orange, which becomes clearer when ripe, and by the pore size and its short tubes. The closest species is Pycnoporus cinnabarinus, which has thicker basidiocarps and whose coloration remains intense in the pores (Valenzuela 1999, Pompa et al. 2011). Habitat: It grows on dead wood and causes white rot. It has been reported in all tropical and subtropical areas of the world, mainly in places altered by man.

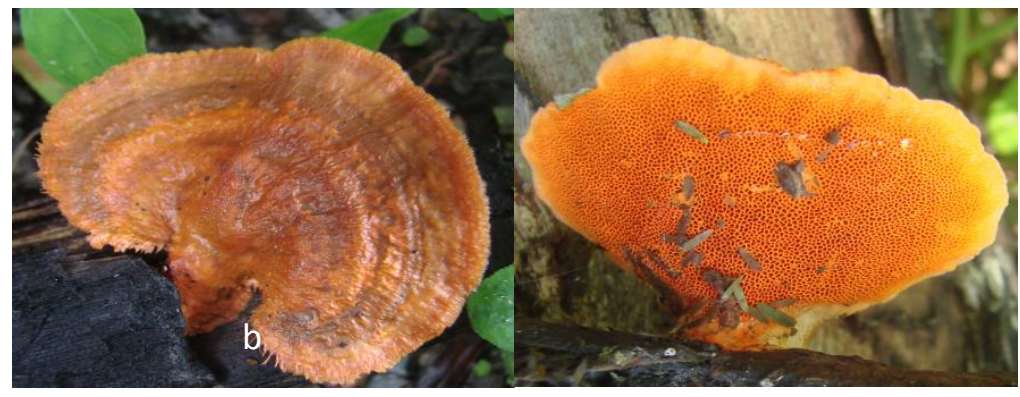

Fig. 1 - Fruiting body of Pycnoporus sanguineus, a) pileus, b) hymenophore.

\section{Pycnoporus cinnabarinus (Jacq.) P. Karst}

Annual basidiocarps, sessile, habitat solitary to gregarious, of consistency coriaceous to corky, with a size of $70 \times 130 \times 140 \mathrm{~mm}$ (diameter, width and thickness respectively). Pileus is dimidiate or elongated, of orange ocher color to pale orange. The color is intense when the specimen is growing, mature or dry specimens are pale and degraded specimens are whitish. The surface of the pileus when young is finely pubescent and it changes quickly to smooth or warty, sometimes in a reticulate pattern, with or without weakly ridged areas, acute margin, smooth to thin wavy, sterile. Context of $10-15 \mathrm{~mm}$, tough and fibrous, usually the color is more persistent in degraded specimens. Hymenophore with pores, coral color to red; angular pores (2-3 per mm); 
concolor tubes to the pileus when young of up to $7 \mathrm{~mm}$ depth (Fig. 2). It grows on dead wood, preferably on Betula, Sorbus aucuparia, Alnus, Corylus, Fraxinus, Malus, Populus, Prunus, Quercus y Salix, causing white rot. Macro-chemical reactions: By adding KOH, the colour quickly changes to black in all its parts.

Microscopic data: trimitic hyphal system with generative hyphae of thin wall, hyaline with fibulae of 1.5-3.5 microns wide, the skeletal hyphae are hyaline, cylindrical spores slightly bent of 5-6 $\times 2-3 \mu \mathrm{m}$, smooth, hyaline and non-amyloid (Table 2). Remarks: The red-orange fruiting bodies and smooth pileus are reliable features to confirm their identification. Due to their striking coloration these are frequently collected and this species is over-represented in herbaria compared with other species (Ryvarden 1978). This species is commonly reported in parts of the northern hemisphere. It is suggested that the presence of Pycnoporus sanguineus in Nordic locations may indicate some tropical reminiscence in the geological past (Guzmán 2003).

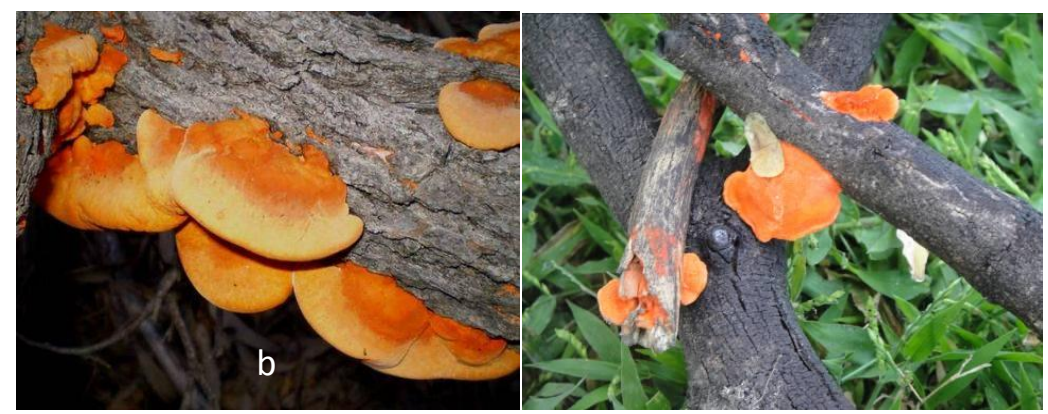

Fig. 2 - Fruiting body of Pycnoporus cinnabarinus, a) pileus, b) hymenophore.

\section{Pycnoporus coccineus (Fr.) Bond \& Sing.}

Annual carpophores, sessile, its habitat is solitary to gregarious, coriaceous consistency to corky, varies from 1-2 cm in diameter in young specimens and $5 \times 15 \times 1 \mathrm{~cm}$ (diameter, width and thickness) in mature specimens. Pileus usually dimidiate, orange color when young and when mature becomes reddish orange. No top surface areas, velvety texture in young specimens and become hard and smooth with age. Obtuse margin, concolor with the upper surface. Context is corky pale of 3-10 mm thick, hymenophore with pores (Table 2), concolor to pileus and sometimes intense orange yellow, dark reddish-orange or bright red; $6-8$ pores per $\mathrm{mm}$, concolor tubes to hymenophore in some specimens, concolor to the pileus of 1.0 to $2.5 \mathrm{~mm}$ deep, cottony consistency to floccose (Fig. 3) (Nobles \& Frew 1962). It grows on dead wood, and causes white rot. Macrochemical reactions: By adding $\mathrm{KOH}$, rapidly changes colour to black.

Microscopic data: trimitic hyphal system, with generative hyphae thin-walled and hyaline. Hyaline skeletal hyphae, the spores are cylindrical to slightly flattened, slightly curved 4.0-5.2 $\times$ 2.0-2.3 $\mu \mathrm{m}$ (diameter, width and thickness), smooth, hyaline, non-amiloyd. Remarks: It is suggested that specimens identified as Pycnoporus coccineus are young specimens or are actively growing of Pycnoporus sanguineus (Ryvarden \& Johansen 1980). This species has been reported in countries bordering the Pacific Ocean and Indic.

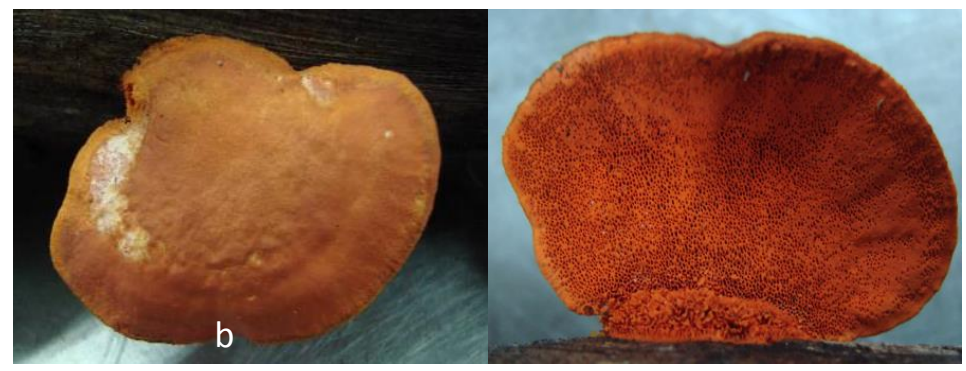

Fig. 3 - Fruiting body of Pycnoporus coccineus, a) pileus, b) hymenophore. 
Pycnoporus puniceus (Fr.) Ryvarden

Grows on deciduous wood, it is a rare species known from Africa (Angola, Ghana, Nigeria, Zaire), Asia (India, Malaysia) and Oceania (New Caledonia) (Ryvarden \& Johansen 1980), and characterized by a basidiocarp with large irregular pores (1-3 per $\mathrm{mm}$ ) (Lesage-Meessen et al. 2011). Microscopic data: trimitic hyphal system (Table 2), thick-walled, hyaline to yellowish, sparsely clamped, about 2.5-4 $\mu \mathrm{m}$ in diameter, yellowish skeletal (Fig. 4).

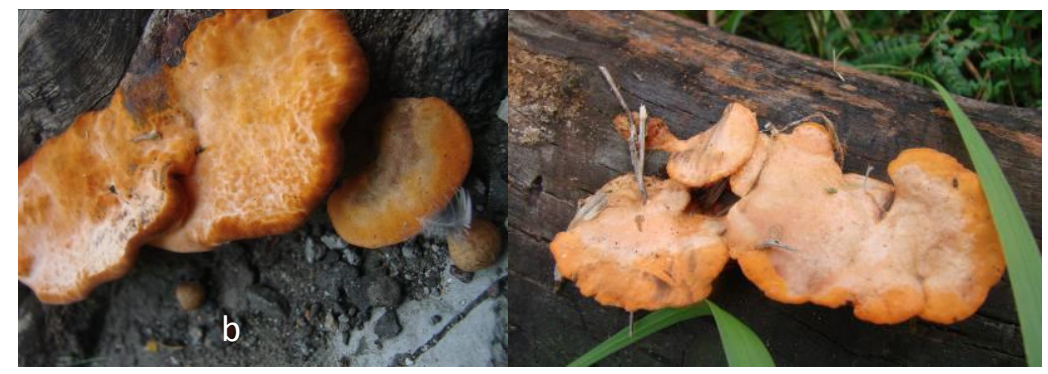

Fig. 4 - Fruiting body of Pycnoporus puniceus, a) pileus, b) hymenophore

Table 2 Main basidiocarp morphological differences among Pycnoporus species.

\begin{tabular}{|c|c|c|c|c|}
\hline Characteristics & $\begin{array}{l}\text { Pycnoporus } \\
\text { sanguineus }\end{array}$ & $\begin{array}{l}\text { Pycnoporus } \\
\text { cinnabarinus }\end{array}$ & $\begin{array}{l}\text { Pycnoporus } \\
\text { coccineus }\end{array}$ & $\begin{array}{l}\text { Pycnoporus } \\
\text { puccineus }\end{array}$ \\
\hline Basidiocarp & $\begin{array}{l}\text { Smooth, flabelliforme } \\
\text { velutinous surface to } \\
\text { glabrous, zoned; } \\
\text { acute margin, smooth } \\
\text { to wavy thin, sterile. }\end{array}$ & $\begin{array}{l}\text { Smooth or warty, } \\
\text { sometimes in a } \\
\text { reticulate patter, with } \\
\text { or without weakly } \\
\text { ridged areas, acute, } \\
\text { smooth to thin margin, } \\
\text { sterile }\end{array}$ & $\begin{array}{l}\text { Hard smooth, } \\
\text { coriaceous } \\
\text { consistency to corky, } \\
1-2 \mathrm{~cm} \\
\text { Obtuse margin }\end{array}$ & $\begin{array}{l}\text { Wrinkled, broadly } \\
\text { attached }\end{array}$ \\
\hline Color & Bright reddish orange & $\begin{array}{l}\text { Orange-ocher to pale } \\
\text { orange }\end{array}$ & Reddish orange & $\begin{array}{l}\text { Dark orange innabar } \\
\text { to darker red, with } \\
\text { darker and lighter } \\
\text { zones ending in the } \\
\text { pore layer reflecting } \\
\text { developmental stages }\end{array}$ \\
\hline Size (mm) & $\begin{array}{l}30-30 \times 22-30 \times 5- \\
10\end{array}$ & $70 \times 130 \times 140$ & $50 \times 150 \times 10$ & $40-50 \times 13 \times 7-10$ \\
\hline Context & $\begin{array}{l}2 \mathrm{~mm} \text {, corky } \\
\text { consistency to } \\
\text { floccose }\end{array}$ & $\begin{array}{l}10-15 \mathrm{~mm} \text {, tough and } \\
\text { fibrous }\end{array}$ & $\begin{array}{l}3-10 \mathrm{~mm} \text {, corcky } \\
\text { pale }\end{array}$ & $\begin{array}{l}\text { Cinnabar to darker } \\
\text { red, with darker and } \\
\text { lighter zones ending } \\
\text { in the pore layer } \\
\text { reflecting } \\
\text { developmental stages. }\end{array}$ \\
\hline Hymenophore & $\begin{array}{l}\text { Orange-red, pores } 4- \\
6 \mathrm{~mm} \text {, tubes } 1 \mathrm{~mm} \\
\text { deep }\end{array}$ & $\begin{array}{l}\text { Coral to red, } 2-3 \\
\text { angular pores per } \mathrm{mm} \text {, } \\
\text { con color tubes } 7 \mathrm{~mm} \\
\text { deep } \\
\text { coriaceous to corky } \\
\text { mature or dry are pale } \\
\text { and whitish in } \\
\text { degraded specimens }\end{array}$ & $\begin{array}{l}\text { Reddish orange } \\
\text { sometimes intense } \\
\text { orange yellow or } \\
\text { bright red, 6-8 pores } \\
\text { per mm, tubes } 1.0- \\
2.5 \mathrm{~mm} \text { deep, cottony } \\
\text { consistency to } \\
\text { fluccose }\end{array}$ & $\begin{array}{l}\text { Large pores } 1-3 \text { per } \\
\mathrm{mm}\end{array}$ \\
\hline $5 \% \mathrm{KOH}$ & $\begin{array}{l}\text { Upon drying becomes } \\
\text { greenish brown }\end{array}$ & Changing to black & Changing to black & Changing to black \\
\hline Hyphal system & Trimitic & Trimitic & Trimitic & Trimitic \\
\hline Spores & $\begin{array}{l}\text { Cylindrical spores } \\
5-6 \times 2-3 \mathrm{~mm} \text { deep }\end{array}$ & $\begin{array}{l}\text { Cylindrical to slightly } \\
\text { bend spores } \\
5-6 \times 2-3 \mathrm{~mm} \text { deep }\end{array}$ & $\begin{array}{l}\text { Cylindrical to slightly } \\
\text { flattened, slightly } \\
\text { curve } 4.0-5.2 \times 2.0- \\
2.3\end{array}$ & $\begin{array}{l}\text { Ellipsoid, thin-walled } \\
\text { and with smooth } \\
\text { walls, } 4.5-6 \times 23 \\
\mu \mathrm{m} \text {. }\end{array}$ \\
\hline
\end{tabular}

(Ryvarden \& Johansen 1980) 


\section{Molecular identification}

In recent years, the most accurate assessment of the identification and diversity of fungi has been achieved using molecular markers, such as, the internal transcribed spacer (ITS) region of ribosomal DNA, and partial sequences of genes encoding subunits of RNA, such as polymerase, $\beta$ tubulin, cellobiohydrolase-C, topoisomerase II and Manganese peroxidase (Hatsch et al. 2004, Wang et al. 2004, Froslev et al. 2005, Tomšovský et al. 2006). There are other techniques used for molecular identification such as RFLP (restriction fragment length polymorphism) and RAPDs (random amplified polymorphic DNA). Ribosomal gene amplification is used to identify microorganisms (White et al. 1990, Dupont et al. 1998). These genes comprise highly conserved and highly variable sequences and can be used to compare species within the same genus phylogenetically and between strains of the same species. The region of nuclear rDNA contains two internal transcribed spacers regions (ITS1 and ITS2) and the gene 5.8S rDNA is used successfully in the determination of phylogenetic relationships among genera and species of fungi. The ITS region is known to show some variability even within species, although their intraspecific variability is often considered limited and clearly separated from interspecific variability. The existence of such a large variability between intra- and interspecific gap is implicitly assumed by automated approaches to species identification, but if indeed intraspecific variability is insignificant in the fungi kingdom, its use remains controversial (Nilsson et al. 2008).

This region can easily be amplified (600-800 bp sequence, which is repeated several times in the genome) with the PCR method using universal primers ITS1 and ITS4. Lomascolo et al. (2002) performed the molecular identification using ribosomal ITS1-5.8S-ITS2 of genomic sequences of 20 strains of Pycnoporus ( 2 of Pycnoporus coccineus, 8 of Pycnoporus cinnabarinus and 10 of Pycnoporus sanguineus), the phylogenetic tree of the sequences obtained grouped the strains according to their geographical origin rather than their taxonomic position. One group included the Asian strains and the other included northern Europe strains. Rungjindamai et al. (2008) performed the molecular characterization (ITS) of basidiomycetes from Thailand, and the species were identified as Pycnoporus puniceus, who formed a group with Pycnoporus sanguineus, grouped in a basal clade. Pycnoporus puniceus is a rare species. This is the first report of this species for Thailand. Ryvarden \& Johansen (1980) have already reported its finding in Malaysia.

Phylogenetic trees inferred from sequences clearly show the difference in the group of strains of Pycnoporus cinnabarinus with the group of strains of Pycnoporus puniceus, strongly confirmed in clades (100\%). The molecular grouping, based in sequences lac 3-1, separated the species by distribution in Pycnoporus sanguineus and Pycnoporus coccineus in four clades and subclades. A neotropical sub-clade, grouped strains of Pycnoporus sanguineus from France, Guiana and Venezuela, corresponding to Pycnoporus sanguineus sensu stricto. In a paleotropical subclade, strains from Madagascar, Vietnam and New Caledonia were pooled and defined as Pycnoporus cf. sanguineus. The clade of Australia corresponded to Pycnoporus coccineus in stricto sensu. The clade in the region of East Asia, and the grouping of strains from China and Japan, formed a group of Pycnoporus coccineus. The analysis of the laccase gene (lac 3-1) of Pycnoporus species highlighted functional diversity of the enzyme associated with the biogeographical origin (LesageMeessen et al. 2011).

\section{Worldwide distribution}

Fungi of the genus Pycnoporus are widely distributed. Some species have been reported in banks of strains (Table 3), and are well researched. The most studied species is Pycnoporus sanguineus, followed by Pycnoporus cinnabarinus then Pycnoporus coccineus and finally Pycnoporus puniceus. These species were described by Nobles \& Frew (1962) and Ryvarden \& Johansen (1980). Pycnoporus sanguineus and Shizophyllum commune have been considered indicators of disturbance species (Díaz-Barriga et al. 1988). Currently in Mexico there are specimens of the Pycnoporus genus in some mycological herbaria such as the Biological Research Center of the Universidad Autónoma del Estado de Morelos (HEMIM), MEXU collection of the Faculty of Sciences of the Universidad Nacional Autónoma de México (UNAM), Institute of 
Biology of the UNAM, National School of Biological Sciences of IPN, University Center for Biological and Agricultural Sciences at the Universidad de Guadalajara.

Table 3 Distribution of some species of the genus Pycnoporus.

\begin{tabular}{|c|c|c|c|c|}
\hline Specie & Strain & Host origen & Geographic origin & Reference \\
\hline \multirow[t]{8}{*}{$\begin{array}{l}\text { Pycnoporus } \\
\text { puniceus }\end{array}$} & BCC26408 & Saprobic on wood & Tammaran Pier, Satun & $\begin{array}{l}\text { Rungjindamai et al. } \\
2008\end{array}$ \\
\hline & ВCC27595 & Saprobic on wood & Tammaran Pier, Satun & $\begin{array}{l}\text { Rungjindamai et al. } \\
2008\end{array}$ \\
\hline & MUCL47083 & Quercus cubana & Pinal del Rio, Cuba & $\begin{array}{l}\text { Lesage-Meessen et } \\
\text { al. } 2011\end{array}$ \\
\hline & MUCL44170 & & & $\begin{array}{l}\text { Lesage-Meessen et } \\
\text { al. } 2011\end{array}$ \\
\hline & MUCL47087 & Quercus cubana & Pinal del Rio, Cuba & $\begin{array}{l}\text { Lesage-Meessen et } \\
\text { al. } 2011\end{array}$ \\
\hline & MUCL53064 & $\begin{array}{l}\text { Old timber, } \\
\text { unidentified }\end{array}$ & $\begin{array}{l}\text { Europe, French Guiana, } \\
\text { Regina Municipality, Les }\end{array}$ & $\begin{array}{l}\text { Lesage-Meessen et } \\
\text { al. } 2011\end{array}$ \\
\hline & & angiosperm & Nouragues Nature & \\
\hline & & & $\begin{array}{l}\text { Reserve, CNRS field } \\
\text { station Inselberg }\end{array}$ & \\
\hline \multirow[t]{6}{*}{$\begin{array}{l}\text { Pycnoporus } \\
\text { coccineus }\end{array}$} & $\begin{array}{l}\text { CBS } 355.63 \\
\text { (BRFM 65) }\end{array}$ & Wood & Solomon Islands & $\begin{array}{l}\text { Lomascolo et al. } \\
2002\end{array}$ \\
\hline & CBS 356.63 & Quercus serrata & Japan & $\begin{array}{l}\text { Lomascolo et al. } \\
2002\end{array}$ \\
\hline & $\begin{array}{l}\text { BRFM } 937 \\
\text { (MUCL 38527) }\end{array}$ & & Japan & Uzan et al. 2010 \\
\hline & $\begin{array}{l}\text { BRFM } 938 \\
\text { (MUCL 38523) }\end{array}$ & Eucalyptus sp. & Australia & Uzan et al. 2010 \\
\hline & $\begin{array}{l}\text { BRFM } 939 \\
\text { (MUCL 38525) }\end{array}$ & $\begin{array}{l}\text { Eucalyptus } \\
\text { marginatus }\end{array}$ & Australia & Uzan et al. 2010 \\
\hline & BCC22930 & $\begin{array}{l}\text { Bark of dead } \\
\text { hardwood tree }\end{array}$ & Thailand & $\begin{array}{l}\text { Thongkred et al. } \\
2011\end{array}$ \\
\hline \multirow[t]{13}{*}{$\begin{array}{l}\text { Pycnoporus } \\
\text { cinnabarinus }\end{array}$} & MUCL 30555 & Forest & Lauzelle forest, Belgium & $\begin{array}{l}\text { Lomascolo et al. } \\
2002\end{array}$ \\
\hline & MUCL 29375 & Wood, ocean & $\begin{array}{l}\text { Madagascar, Indian } \\
\text { ocean }\end{array}$ & $\begin{array}{l}\text { Lomascolo et al. } \\
2002\end{array}$ \\
\hline & MUCL 38420 & $\mathrm{Nd}$ & Australia & $\begin{array}{l}\text { Lomascolo et al. } \\
2002\end{array}$ \\
\hline & MUCL 38480 & $\mathrm{Nd}$ & Austria & $\begin{array}{l}\text { Lomascolo et al. } \\
2002\end{array}$ \\
\hline & CBS 101046 & $\mathrm{Nd}$ & Melbourne, Australia & $\begin{array}{l}\text { Schliephake et al. } \\
2000\end{array}$ \\
\hline & I-937 (CNCM) & Rotten wood & Finland & $\begin{array}{l}\text { Lomascolo et al. } \\
2002\end{array}$ \\
\hline & BRFM 44 & $\begin{array}{l}\text { Banque de } \\
\text { Resources } \\
\text { Fongiques de } \\
\text { Marseille }\end{array}$ & Mar-seille, France & Alves et al. 2004 \\
\hline & F-076.859 & $\mathrm{Nd}$ & Spain & Suay et al. 2000 \\
\hline & 0261 (BIP) & $\mathrm{Nd}$ & Russia & Herpoël et al. 2000 \\
\hline & 0263 (BIP) & $\mathrm{Nd}$ & Russia & Herpoël et al. 2000 \\
\hline & 0692 (BIP) & $\mathrm{Nd}$ & Russia & Herpoël et al. 2000 \\
\hline & I-938 (CNCM) & $\mathrm{Nd}$ & France & Herpoël et al. 2000 \\
\hline & VKM F-3226 & Betula sp. & $\begin{array}{l}\text { RussiaChelyabinsk } \\
\text { Region }\end{array}$ & $\begin{array}{l}\text { Gómez-Toribio et. } \\
\text { al. } 2009\end{array}$ \\
\hline
\end{tabular}




\begin{tabular}{|c|c|c|c|c|}
\hline Specie & Strain & Host origen & Geographic origin & Reference \\
\hline Pycnoporus & F-057.299 & $\mathrm{Nd}$ & Spain & Suay et al. 2000 \\
\hline \multirow[t]{35}{*}{ sanguineus } & CBS 357.63 & Pinus echinata & Georgia, USA & Halaouli et al. 2005 \\
\hline & $\mathrm{SN}$ & $\mathrm{Nd}$ & Kepong, Malaysia & Teoh et al. 2011 \\
\hline & SN & Parit Forest & $\begin{array}{l}\text { Reserve, Perak, } \\
\text { Malaysia. }\end{array}$ & $\begin{array}{l}\text { Zulfadhly et al. } \\
2001\end{array}$ \\
\hline & CBS 358.63 & Shorea robusta & India & $\begin{array}{l}\text { Lomascolo et al. } \\
2002\end{array}$ \\
\hline & CBS 614.73 & Angiosperm wood & Sri Lanka & $\begin{array}{l}\text { Lomascolo et al. } \\
2002\end{array}$ \\
\hline & G05 & $\begin{array}{l}\text { Rotten wood of } \\
\text { broad-leaves tree }\end{array}$ & $\begin{array}{l}\text { Guangdong: Mt. Dinghu, } \\
\text { China }\end{array}$ & $\begin{array}{l}\text { Lomascolo et al. } \\
2002\end{array}$ \\
\hline & W006 & $\begin{array}{l}\text { Rotten wood of } \\
\text { broad-leaves tree }\end{array}$ & $\begin{array}{l}\text { Guangxi: Mt. Daming, } \\
\text { China }\end{array}$ & $\begin{array}{l}\text { Lomascolo et al. } \\
2002\end{array}$ \\
\hline & $006-2$ & $\begin{array}{l}\text { Rotten wood of } \\
\text { broad-leaves tree }\end{array}$ & $\begin{array}{l}\text { Guangxi: Mt. Daming, } \\
\text { China }\end{array}$ & $\begin{array}{l}\text { Lomascolo et al. } \\
2002\end{array}$ \\
\hline & W 3008 & $\begin{array}{l}\text { Rotten wood of } \\
\text { broad-leaves tree }\end{array}$ & $\begin{array}{l}\text { Guangxi: Mt. Daming, } \\
\text { China }\end{array}$ & $\begin{array}{l}\text { Lomascolo et al. } \\
2002\end{array}$ \\
\hline & G53 & $\begin{array}{l}\text { Rotten wood of } \\
\text { Pinus sp. }\end{array}$ & $\begin{array}{l}\text { Hainan: Bawangling, } \\
\text { China }\end{array}$ & $\begin{array}{l}\text { Lomascolo et al. } \\
2002\end{array}$ \\
\hline & G66 & Rotten hardwood & $\begin{array}{l}\text { Hainan: Tunchang, } \\
\text { China }\end{array}$ & $\begin{array}{l}\text { Lomascolo et al. } \\
2002\end{array}$ \\
\hline & H2008 & Rotten hardwood & $\begin{array}{l}\text { Hainan: Bawangling, } \\
\text { China }\end{array}$ & $\begin{array}{l}\text { Lomascolo et al. } \\
2002\end{array}$ \\
\hline & $\mathrm{H} 2180$ & Rotten hardwood & $\begin{array}{l}\text { Hainan: Qiongzhong, } \\
\text { China }\end{array}$ & $\begin{array}{l}\text { Lomascolo et al. } \\
2002\end{array}$ \\
\hline & W28 & $\begin{array}{l}\text { Rotten wood of } \\
\text { broad-leaved tree }\end{array}$ & $\begin{array}{l}\text { Jiagdaqi, Mongolia, } \\
\text { China }\end{array}$ & Halaouli et al. 2005 \\
\hline & G118 & $\begin{array}{l}\text { Rotten wood of } \\
\text { broad-leaved tree }\end{array}$ & $\begin{array}{l}\text { Heilongjiang, Huma, } \\
\text { China }\end{array}$ & Halaouli et al. 2005 \\
\hline & Dis 343d & Theobroma cacao & $\begin{array}{l}\text { Maldonado, Pichincha } \\
\text { Province, west Ecuador }\end{array}$ & Crozier et al. 2006 \\
\hline & Dis $343 \mathrm{f}$ & Theobroma cacao & $\begin{array}{l}\text { Maldonado, Pichincha } \\
\text { Province, west Ecuador }\end{array}$ & Crozier et al. 2006 \\
\hline & Dis343c & Theobroma cacao & $\begin{array}{l}\text { Maldonado, Pichincha } \\
\text { Province, west Ecuador }\end{array}$ & Crozier et al. 2006 \\
\hline & BCC26410 & Oil palm & $\begin{array}{l}\text { Sai Bor oil plantation, } \\
\text { Trang }\end{array}$ & $\begin{array}{l}\text { Rungjindamai et al } \\
2008\end{array}$ \\
\hline & BAFC 2126 & & Misiones Argentina & Shimizu et al. 2009 \\
\hline & BAFC: 2341 & & Misiones Argentina & $\begin{array}{l}\text { Bobadilla et al. } \\
2007\end{array}$ \\
\hline & SN & & Uruguayan & Gioia et al. 2014 \\
\hline & BRFM 892 & $\mathrm{Nd}$ & French Guiana & Uzan et al. 2010 \\
\hline & BRFM 893 & $\mathrm{Nd}$ & French Guiana & Uzan et al. 2010 \\
\hline & BRFM 895 & $\mathrm{Nd}$ & French Guiana & Uzan et al. 2010 \\
\hline & BRFM 896 & $\mathrm{Nd}$ & French Guiana & Uzan et al. 2010 \\
\hline & BRFM 897 & $\mathrm{Nd}$ & French Guiana & Uzan et al. 2010 \\
\hline & BRFM 899 & $\mathrm{Nd}$ & French Guiana & Uzan et al. 2010 \\
\hline & BRFM 900 & $\mathrm{Nd}$ & French Guiana & Uzan et al. 2010 \\
\hline & BRFM 901 & $\mathrm{Nd}$ & French Guiana & Uzan et al. 2010 \\
\hline & BRFM 902 & $\mathrm{Nd}$ & French Guiana & Uzan et al. 2010 \\
\hline & BRFM 903 & $\mathrm{Nd}$ & French Guiana & Uzan et al. 2010 \\
\hline & BRFM 905 & $\mathrm{Nd}$ & French Guiana & Uzan et al. 2010 \\
\hline & BRFM 906 & $\mathrm{Nd}$ & French Guiana & Uzan et al. 2010 \\
\hline & BRFM 942 & $\mathrm{Nd}$ & Vietnam & Uzan et al. 2010 \\
\hline
\end{tabular}




\begin{tabular}{|c|c|c|c|c|}
\hline Specie & Strain & Host origen & Geographic origin & Reference \\
\hline & BRFM 943 & $\mathrm{Nd}$ & Vietnam & Uzan et al. 2010 \\
\hline & BRFM 23 & $\mathrm{Nd}$ & China & Uzan et al. 2010 \\
\hline & BRFM 3 & $\mathrm{Nd}$ & China & Uzan et al. 2010 \\
\hline & BRFM 6 & $\mathrm{Nd}$ & China & Uzan et al. 2010 \\
\hline & BRFM 11 & $\mathrm{Nd}$ & China & Uzan et al. 2010 \\
\hline & BRFM 66 & $\mathrm{Nd}$ & China & Uzan et al. 2010 \\
\hline & BRFM 881 & rotten wood & Venezuela & Uzan et al. 2010 \\
\hline & BRFM 979 & $\mathrm{Nd}$ & French New Caledonia & Uzan et al. 2010 \\
\hline & BRFM 980 & $\mathrm{Nd}$ & French New Caledonia & Uzan et al. 2010 \\
\hline & BRFM 981 & $\mathrm{Nd}$ & French New Caledonia & Uzan et al. 2010 \\
\hline & $\mathrm{CCB} 175$ & $\mathrm{Nd}$ & São Paulo, Brazil & Rosa et al. 2003 \\
\hline & CCB113 & $\mathrm{Nd}$ & São Paulo, Brazil & Rosa et al. 2003 \\
\hline & $\mathrm{Bm}$ & $\mathrm{Nd}$ & $\begin{array}{l}\text { Mato Groso do Sul, } \\
\text { Brazil }\end{array}$ & Rosa et al. 2003 \\
\hline & $\mathrm{CCB} 273$ & $\mathrm{Nd}$ & São Paulo & Rosa et al. 2003 \\
\hline & CCB294 & $\mathrm{Nd}$ & São Paulo & Rosa et al. 2003 \\
\hline & $\mathrm{CCB} 277$ & $\mathrm{Nd}$ & São Paulo & Rosa et al. 2003 \\
\hline & CCT-4518 & $\begin{array}{l}\text { Fundação André } \\
\text { Tosello, } \\
\text { Campinas }\end{array}$ & São Paulo, Brazil & Garcia et al. 2007 \\
\hline & 118775 & & $\begin{array}{l}\text { Medellín (Antioquia), } \\
\text { Colombia }\end{array}$ & Correa et al. 2005 \\
\hline & MEXU 25347 & Oil-polluted & Veracruz, México & $\begin{array}{l}\text { Dantán-González et } \\
\text { al. } 2008\end{array}$ \\
\hline & $\begin{array}{l}\text { HEMIM 52, 52, } \\
53,54\end{array}$ & $\mathrm{Nd}$ & Morelos México & $\begin{array}{l}\text { Acosta-Urdapilleta } \\
\text { et al. } 2010\end{array}$ \\
\hline
\end{tabular}

CNCM, Collection Nationale de Cultures de Microorganismes, Institut Pasteur, France; MUCL, Mycotheque de l'Universite Catholique de Louvain, Belgium; BIP, Botanical Institut of St Petersburg; BRFM, Banque de Ressources Fongiques de Marseille of the International Centre of Microbial Resources, Marseille, France; CBS, Centraalbureau voor Schimmelcultures, Utrecht, The Netherlands; MEXU Herbario Nacional de México; Herbario Micologico de Morelos (HEMIM).

\section{Biotechnological potential application}

\section{Medical \& Pharmaceutical}

As previously mentioned, Pycnoporus cinnabarinus, Pycnoporus coccineus and Pycnoporus sanguineus are able to synthesize a salmon red color pigment that sometimes can be described even as scarlet or vermillion which is a characteristic feature of the species. With the aging process the carpophore turns to an orange or pink color making it difficult in morphological characterization. Biological pigments or biochromes are substances produced by living organisms that have a color resulting from selective color absorption. Several compounds with structures of phenozaxone base are considered to be pigments known also as alkaloids or polyphenols. Most alkaloids have strong physiological effects in animals even at low doses so have psychoactive, medicinal and pharmaceutical applications. It has been reported that of the pigments of Pycnoporus strains; cinnabarin, cinnabarinic acid and tramesanguin are the main components, and act as antioxidants, free radical scavengers, antifungals (Borderes et al. 2011), anticarcinogens (Smânia et al. 2003), are immunomodulatory, larvicidal (Bücker et al. 2013), have lechmanicidal activity (Correa et al. 2006) and antiviral, antibacterial (Smânia et al. 1995, 2003) and anti-inflammatory activity (Kuanget et al. 2010). Pigment characterization, and its biosynthesis have been described by several authors. It is indicated that a phenoxazine-3-one (a nitrogen heterocycle) type structure is responsible for the above activities and for the red color pigment of these strains (Achenbach \& Blüm 1991). 
Phenoxazine-3-one type structure occurs as the central core of a number of naturally occurring chemical compounds such as the antibiotic actinomycins (polypeptide antibiotics), litmus (7-hydroxyphenoxazone mix), and orcein (7-hydroxyphenoxazone mix). Cinnabarin has a basic ring similar to that of actinomycin $\mathrm{D}$, which is an antibiotic used routinely to treat certain forms of cancer. However, actinomycin D is very toxic to humans. By contrast, cinnabarin at a concentration of $0.31 \mathrm{mg} / \mathrm{mL}$ had no effect on mouse neuroblastoma cells, and at doses of $1000 \mathrm{mg} / \mathrm{kg}$ it did not cause toxic effects in mice. In addition, at concentrations of $0.31 \mathrm{mg} / \mathrm{mL}$, it produced a 4 -fold reduction in the titers of the rabies virus and cinnabarinic acid is active against several Grampositive bacteria of the Streptococcus group (Jiang et al. 2011).

Cinnabarinic acid is a red pigmented phenoxazinone synthesized as a by-product of the kynurenine pathway, which derives from the condensation of two molecules of 3hydroxyanthranilic acid. Fruiting bodies and mycelial growth of Pycnoporus cinnabarinus were screened and found to possess antibacterial properties (Fajana et al. 1999, Shittu et al. 2005). The concentrated culture fluid of Pycnoporus cinnabarinus showed biological activity against a variety of bacterial strains, with maximal inhibitory effect for Gram-positive bacteria of the genus Streptococcus. Laccase secreted by the fungus oxidizes the precursor 3-hydroxyanthranilic acid to cinnabarinic acid, a reaction that is necessary for the production of antibacterial compounds. The biological activity of the concentrated culture of Pycnoporus cinnabarinus was nearly identical with that of cinnabarinic acid, synthesized by purified laccase in vitro (Eggert 1997). In another study, a liquid culture filtrate of Pycnoporus cinnabarinus showed positive antibacterial effects against the growth of the Gram-negative bacteria Escherichia coli and Pseudomonas aeruginosa as well as Gram-positive Staphylococcus aureus. The culture filtrate was also used against mycelial growth and mycelial weight of three plant pathogenic fungi, Botrytis cinerea, Colletotrichum gloeosporioides [Glomerella cingulata] and Colletotrichum miyabeanus, showing good inhibitory effects (Imtiaj et al. 2007).

Anti-tumor effects of polysaccharides extracted from the mycelial culture of Pycnoporus cinnabarinus and administered intraperitoneally into white mice at a dosage of $300 \mathrm{mg} / \mathrm{kg}$ inhibited the growth of Sarcoma 180 and Ehrlich solid cancers by 90\%. More over cinnabarinic acid has been shown to possess strong apoptosis-inducing activity and results in the production of reactive oxygen species with loss of mitochondrial membrane potential and reduces caspase activation. Its biological function is largely unknown, however, it is a modulator of immune response in autoinmmune disorders or an immune modulator (Hayashi et al. 2001). Indoleamine-2,3dioxygenase is induced by proinflammatory cytokines, such as interferon- $\gamma$; therefore, the kynurenine pathway is activated in the context of neuroinflammation, as occurs in the ischemic brain or in the brain of patients with HIV infection. Neuroactive metabolites of the kynurenine pathway, such as quinolinic acid, kynurenic acid, and xanthurenic acid, are involved in synaptic signaling and in mechanisms of neurodegeneration/neuroprotection. Quinolinic acid, acts as an orthosteric agonist of N-methyl-d-aspartate (NMDA) receptors, whereas kynurenic acid and its synthetic derivatives are competitive antagonists at the coagonist glycine site of NMDA receptors. Recently, cinnabarinic acid was reported as a novel endogenous orthosteric agonist of mGlu4 receptors endowed with neuroprotective activity (Fazio et al. 2012).

Among the natural compounds of the phenoxazine class are tramesanguin, a crystaline pigment that was isolated from these Pycnoporus strains or Coriolus sanguineus and questiomycin an extract from certain Streptomyces and Waksmania species. Besides cinnabarin, cinnabarinic acid and tramesanguin and at least 6 more different aminophenoxazine derivative compounds have been reported in these three Pycnoporus strains. These different aminophenoxazine derivatives can be synthesized enzymatically at room temperature and without addition of dangerous chemicals during bioprocesses catalyzed by laccase or phenozaxineone synthase, as well as cinnabarin, cinnabarinic acid and tramesanguin producing interesting color with applications such as textile and hair dyes. Phenoxazine derivatives can be used as platform chemicals to synthesize other compounds using synthetic biotechnology processes based on laccases, tyrosinases, phenoxazine one synthase and other enzymes with broad applications (Forte et al. 2010). 
The presence of cinnabarin or poliporin in Pycnoporus sanguineus was reported first by Bose (1946) followed by other researchers (Gripenberg 1951, 1958, 1963, Cavill et al. 1953, Achenbach \& Blümm 1991). Polystictin or 1-carboxy-2-amino-9 hydroxy methyl phenoxazin-3one (de Oliveira et al. 2007); tramesanguin or 1-carboxy-2-amino-9 formylphenoxazine-3-one (Gripenberg 1958); cinnabarinic acid (2-Amino-3-oxo-3H-phenoxazine-1,9-dicarboxylic acid); $\alpha$ aminophenoxazone; pycnoporin or 2-Amino-9-[hydroxy(methoxy)methyl]-3-oxo-3H-phenoxazine1-carboxylic acid (Gripenberg 1951; Dias \& Urban 2009) were also reported. Achenbach \& Blümm (1991), reported a 2-amino-phenoxazin-3-one type phenoxazine ether pycnosanguin and an unsubstituted phenoxazin-3-one in Pycnoporus sanguineus carpophores. Dias \& Urban (2009) added to the list, 2-amino-9 formylphenoxazone-1-carbonic acid; 9-hydroximethyl-2-methylamino phenoxazone-1-carbonic acid methyl ester; and the previous reported un-substituted phenoxazone or 3H-Phenoxazin-3-one; o-acetyl cinnabarin (1-carboxy-2-amino-9 acetyl phenoxazine-3 one). The structures of some of these compounds are shown in Table 4.

Table 4 Phenoxazone compounds in Pycnoporus strains.

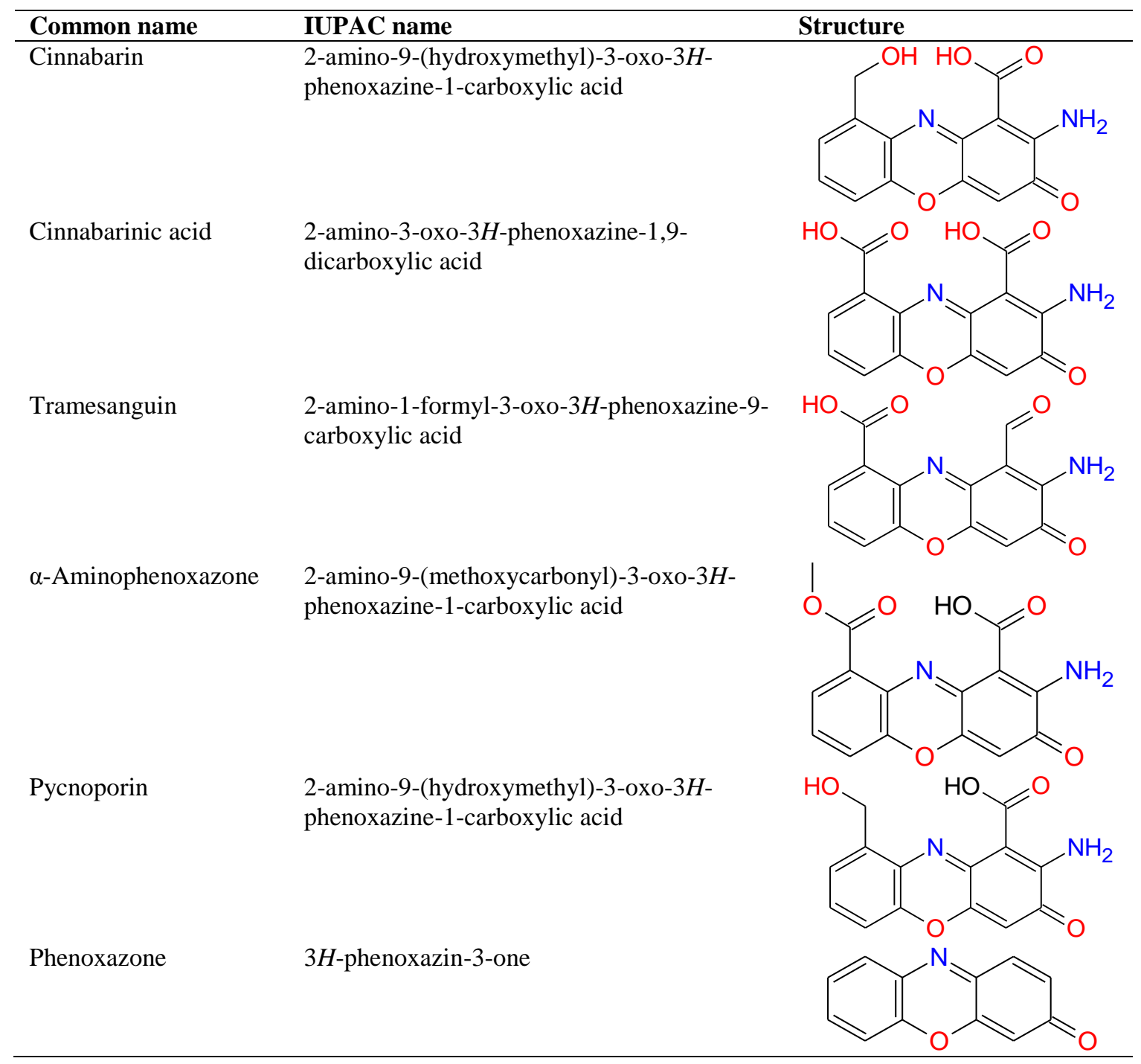

Ethnomycological notes mentioned that Pycnoporus sanguineus is used to help relieve symptoms of arthritis, gout, styptic, sore throats, ulcers, tooth aches, fevers, and hemorrhages in native people from Australia, Brazil and Africa. Moreover, Pycnoporus sanguineus liophilized infusion in potato broth displays antibacterial activity against Escherichia coli, Streptococcus pyogenes (Group A Streptococci), Pseudomonas aeruginosa, Salmonella typhiand and Staphylococcus aureus (Smânia et al. 1995). Among 11 bacteria isolated from food, cinnabarin 
inhibited the bacteria growth by $0.0625 \mathrm{mg} / \mathrm{mL}$ (Smânia et al. 1995). Klebsiella pneumonia was the least sensitive $(>4.0 \mathrm{mg} / \mathrm{mL})$. Smânia et al. (1997), reported that Pycnoporus sanguineus was grown in potato dextrose broth and the best conditions for producing cinnabarin were initial medium $\mathrm{pH} 9.0,25^{\circ} \mathrm{C}$, under light. Antimicrobial activity has been reported from Pycnoporus sanguineus mycelium grown in petri dishes against Bacillus subtilis, Burkholderia unamae, Escherichia coli, Listeria monocytogenes, Shigella flexneri, Salmonella typhi, Staphylococcus aureus and Streptococcus agalactiae. From fruiting bodies, Pycnoporus sanguineus cultivated on oak sawdust showed the highest yield of cinnabarin $(68 \mathrm{mg} / \mathrm{g})$, and it was active at minimal inhibitory concentrations between $41-140 \mathrm{mM}$ against Escherichia coli, Listeria monocytogenes, Salmonella typhi, and Staphylococcus aureus. It also mentioned that cinnabarin obtained from mycelium grown in petri dishes with potato-dextrose agar, whole wheat flour agar or either phosphate agar containing 3\% w/v wheat grain, oat straw or aquatic lily, were more active than that from fruiting bodies; they reported Pycnoporus sanguineus growth, pigment production and antimicrobial activity in liquid and solid-state cultures (Acosta-Urdapilleta et al. 2010).

Uzan et al. (2010) described the oxidation of monomeric and dimeric non-phenolic lignin model compounds such as veratryl alcohol and adlerol by laccase of Pycnoporus sanguineus, testing different natural and synthetic redox mediators at different $\mathrm{pH}$. The 1-Hydroxybenzotriazole (HBT), a synthetic mediator, was the most efficient redox mediator and allowed $100 \%$ oxidation of veratryl alcohol into veratraldehyde and $86 \%$ oxidation of adlerol into adlerone. It has been reported that Pycnoporus sanguineus is able to produce fluorescence compounds when grown in liquid or on solid substrates (Acosta-Urdapilleta et al. 2010).

Pycnoporus cinnabarinus (Jacq.) Fr., (1881) is able to produce the three pigments cinnabarin, cinnabarinc acid and tramesanguin (Sullivan \& Henry 1971, Eggert et al. 1996). However, it produces cinnabarinic acid as the main metabolite and it is responsible for its antimicrobial activity. Concentrated liquid culture of this strain has a maximal inhibitory effect towards Gram-positive bacteria of the genus Streptococcus. Inhibitory antimicrobial activity was higher for Gram-positive than Gram-negative bacteria (Eggert 1997). Cinnabarinic acid production by this strain has been studied by several researchers and their work has granted very interesting applications. Gripenberg (1958) reported cinnabarinic acid is biosynthesized from 3hydroxyanthranilic acid units formed from tryptophan transformation products. Cinnabarinic acid, can also be obtained in a non-enzymatic process by action of active oxygen species and various transition metals (Eggert et al. 1995). For instance compounds such as o-aminophenol often couple spontaneously to form cyclic phenoxazine-one derivatives by an oxidation process, because of its high reactivity. 3-hydroxyanthranilic acid is coupled spontaneously to a phenoxazin-one derivative, cinnabarinic acid. In addition, it can be obtained enzymatically by peroxidase, catalase, tyrosinase or laccase. However, laccase is not capable of non-phenolic lignin structure degradation without a chemical redox mediator because of their low redox-potentials (Eggert et al. 1995).

To overcome the redox potential barrier, Pycnoporus cinnabarinus produces a metabolite that can mediate the oxidation of non-phenolic substrates by laccase; which is 3-hydroxyanthranilic acid, a laccase mediator. O-aminophenol and 3-hydroxyanthranilic acid are metabolites of the kynurenine pathway and act as precursors of cinnabarinic acid. Anthranilic acid is an intermediate of tryptophan synthesis and 3-hydroxyanthranilic acid occurs by hydroxylation of anthranilic acid in the shikimic acid pathway. The reaction resembles the synthesis of actinomycin D by the blue copper enzyme, phenoxazinone synthase, in Streptomyces antibioticus and other pigments (Turner 1971). Color phenoxazinone structures substrates can be obtained by laccase activity of Pycnoporus cinnabarinus such as 4-methyl-3-hydroxyanthranilic acid (Osiadacz et al. 1999), 3amino-4-hydroxybenzenesulfonic acid (Forte et al. 2010), and 3-hydroxyorthanilic acid when glucose is the carbon source, then cinnabarinic acid can be produced by laccase induced oxidation of 3-hydroxyanthranilic acid in batch cultures according to Eggert et al. (1995). In Pycnoporus cinnabarinus, laccase purified from liquid cultures was found to be important for synthesis of the phenoxazinone pigments which give the fruiting bodies a red color (Eggert et al. 1995). 
The phenoxazinone pigments and, laccase activity can also be linked to the antimicrobial activity of this organism (Eggert et al. 1997). A strain of Pycnoporus cinnabarinus ss3 was reported to produce up to $29,000 \mathrm{U} / \mathrm{L}$ of laccase in the presence of ferulic acid as aromatic inducer. The presence of two genes encoding for two laccase isoenzymes, LAC I and LAC II were reported with applications in enzymatic delignification of wheat straw pulp and for the reticulation of phenolic compounds into agro-polymers (Figueroa-Espinoza \& Rouau 1998). The results obtained in vitro confirm the role of laccase in the synthesis of this chromophoric compound as a product of the coupling reaction between unstable aminophenolic radicals (Eggert et al. 1995). The effect of ethanol to increase laccase yield by Pycnoporus cinnabarinus ss3, compared to that of ferulic acid indicated, in the presence of $35 \mathrm{~g} / \mathrm{L}$ ethanol, laccase activity (266,600 U/L) and productivity (19,000 U/L day) were nine- and five-fold higher than those of ferulic acid-induced cultures, and 155 and 65 fold higher than those of control cultures, respectively (Herpoël et al. 2002).

A temperature-dependent change of cinnabarinic acid production was investigated using 3hydroxyanthranilic acid and laccases to produce cinnabarinic acid in stirred tank reactors. The best inducing conditions included liquid media suplemented with $5 \mathrm{~g} / \mathrm{L}$ maltose and $2.5 \mathrm{~g}$ ammonium tartrate at $26^{\circ} \mathrm{C}$ for large scale applications (Göçenoğlu \& Pazarlioglu 2014). 3-hydroxyanthranilic acid is produced by interferon-gamma-primed mononuclear phagocytes in large amounts, therefore, this reaction is very important in clinical studies, since 3-hydroxyanthranilic acid acts as a powerful scavenger of reactive oxygen species. In mammalian tissues, cinnabarinic acid is produced by the peroxyl radical-mediated oxidation of 3-hydroxyanthranilic acid and it might prevent oxidative damage in mammalian tissues (Eggert et al. 1995).

Transformation of the selected precursors into intensive and non-toxic products in liquid culture by actively growing fungal biomass was studied. Stable lasting products were obtained using oxygen as a clean oxidant. Further applicability of the fungi in the synthesis of new colored molecules, is currently promising. Colored products can be used in applications in cosmetic and food industries and as textile or hair dyes. All these products have valuable dyeing properties (Polak \& Jarosz-Wilkołazka 2010). In addition to their excellent coloring properties, phenoxazinones are non-toxic and can be synthesized at room temperature and without addition of dangerous chemicals during bioprocesses catalyzed by laccase. Additionally, the phenoxazinone part of actinomycin-D and its amino derivatives are known to exhibit various fluorescence properties, which have been used in the development of probes in the field of histochemistry and molecular biology

Pycnoporus coccineus (Fr.) Bondart \& Singer (1941), is the only Pycnoporus strain reported to have phenoxazinone synthase enzyme (Nair \& Vining 1964, Le Roes-Hill et al. 2009), and it is also a member of the blue copper oxidase family, then like laccases and tyrosinases, the reaction mechanism mediated by this enzyme is similar to other multicopper oxidases. Interestingly the mammalian protein, ceruloplasmin, as well as laccase, is a member of the blue copper oxidase class of enzymes that catalyzed 3-hydroxyanthranilic acid coupling to cinnabarinic acid (Eggert et al. 1995). There are just four of these enzymes listed in the enzyme databases, these are: from Bauhinia monandra, Tecoma stans, Pycnoporus coccineus, Streptomyces griseus subsp. griseus and the phsA from $S$. antibioticus. The phenoxazine-one sinthase enzyme from Pycnoporus coccineus requires $\mathrm{Mn}^{2+}$ and riboflavin 50-monophosphate and is typically inactive in the absence of flavin mononucleotide (Le Roes-Hill et al. 2009). Its applications are important in several industrial processes such as in the textile industry for dyeing natural fabrics or hair (Shin et al. 2001, Le Roes-Hill et al. 2009). When 3-hydroxyorthanilic acid is converted into aminophenoxazine derivatives with sulfonyl groups, solubility is increased in water and so can be considered as a green chemistry process, it is colorful and can be used as textile dyes for dyeing natural fabrics and for biosensors.

\section{Aroma}

An aroma is a chemical compound that has a smell or odor, and when it is sufficiently volatile, it can be transported to the olfactory system. Flavors affect both the sense of taste and 
smell, whereas fragrances affect only smell. Flavors tend to be naturally occurring, and fragrances tend to be synthetic. Aroma compounds can be found in food, wine, spices, perfumes, fragrance oils, and essential oils. Indeed, many of the aroma compounds play a significant role in the production of flavorants (Fahlbusch et al. 2003). For years companies had directed their attention towards natural flavor compounds of biological origin. Among them plants had been an important source of essential oils and flavors, however, active components are often present in minor quantities making isolation difficult and the flavor products are expensive.

Most available flavor compounds are produced via chemical synthesis or extraction, however, sometimes there is formation of undesirable racemic mixtures and there is growing aversion of the consumer towards chemicals added to food, cosmetics and other household products. Because of that, a directly viable alternative route for flavor synthesis is based on microbial processes, i.e. fermentation (de novo) and bioconversion of appropriate precursor compounds based on microorganisms (bacteria, fungi, yeasts) and their enzymes.

In parallel a high demand for natural ingredients in food, cosmetics and other industries, has directed researches to aroma compounds with desirable antioxidant properties such as the hydroxyl cinnamic acids, due mainly to its occurrence in nature and radical scavenging activity. These compounds exist predominantly as hydroxybenzoic and hydroxycinnamic acids. Metabolic pathways of p-coumaric acid had been suggested mainly to explain the ability of Pycnoporus cinnabarinus to produce aromatic compounds based on the different metabolites identified. Pycnoporus cinnabarinus is able to produce methyl anthranilate de novo in culture conditions combining low nitrogen concentration, maltose as carbon source and uncontrolled culture $\mathrm{pH}$ (Gross et al. 1990). Pycnoporus cinnabarinus has been reported as a vanillin producer from ferulic acid (Gross et al. 1991, Stentelaire et al. 2000).

A new two-step process for the production of pure vanillin from autoclaved maize bran was designed involving Aspergillus niger and Pycnoporus cinnabarinus. Two strategies were defined using autoclaved maize bran; to improve Aspergillus niger grown on sugar beet pulp to produce high levels of polysaccharide-degrading enzymes, including feruloyl esterases, and to transform ferulic acid into vanillic acid (Bonnin et al. 2002). Certain strains of Pycnoporus cinnaburinus under laboratory culture conditions can form methyl anthranilate, an important natural flavouring and secondary metabolites important in biotechnology areas of food. There is a hypothetical relationship between aroma and pigment synthesis in Pycnoporus strains. Benzaldehyde was obtained using L-phenylalanine as substrate with Pycnoporus cinnabarinus (Lomascolo et al. 1999). Fungal transformation of p-coumaric acid into caffeic acid, a strong antioxidant is possible by Pycnoporus cinnabarinus cultures grown with high p-coumaric acid feeding rates (EstradaAlvarado et al. 2003). The white-rot basidiomycetes, and especially the genus Pycnoporus, represent major biotechnological agents for generating, de novo or by bioconversion, natural aromas for industry when grown in standard media or in the presence of precursors (Lomascolo et al. 2002).

\section{Pycnoporus as enzyme producer}

The photomass is the plant matter produced by photosynthesis and lignocellulose is the major component representing around half of this matter. It is composed of polysaccharides (cellulose and hemicellulose) mainly and lignin, representing the most abundant renewable organic resource in soil. Its components are strongly intermeshed and chemically bonded by non-covalent forces and by covalent cross-linkages (Pérez et al. 2002). Polysaccharides are polymers of monosaccharides connected to each other by glycosidic bonds. Among the main functions of these compounds, have been reported as structural components, storage materials and protective substances. Structural polysaccharides are either fibrous polysaccharides, mainly cellulose in higher plants and some algae or chitin in yeast and fungi or matrix polysaccharides, for example arabinoxylans, galactomannans or pectins in plants. Starch, glycogen, some $\beta$-glucans, fructans and some galactomannans are examples of storage polysaccharides. Protective polysaccharides include extracellular polysaccharides from microorganisms or exudate gums from plants (Aspinall 1982). 
Based on the complex composition of lignocellulose, its degradation is very difficult, this process can be carried out mainly by microorganisms with complex enzymes including hydrolases and phenoloxidases. Some fungi organisms are very efficient degraders of lignocellulosic material. There are two main groups of wood decay fungi, including those in the division Basidiomycota, commonly called Basidiomycetes, and those included in the division Ascomiceta, or Ascomycetes. These fungi are classified according to the way they act on wood. White-rot fungi break down all major wood components (cellulose, hemicelluloses and lignin) and commonly cause bleached rotted wood. Brown-rot fungi primarily decay cellulose and hemicellulose in wood, leaving a brown residue of lignin, and the soft-rot fungi preferentially degrade cellulose (Leonowicz et al. 1999, Rabinovich et al. 2004).

White-rot fungi are capable of degrading some xenobiotic compounds and different kinds of environmental pollutants due to its ligninolytic enzyme system. Ligninolytic enzymes have potential applications in a large number of fields, including chemical, fuel, food, agricultural, paper, textile, cosmetic industrial sectors and more. Species of Pycnoporus genus, produce diverse enzymes. There are reports about the production of $\beta-\mathrm{N}$-acetylhexosaminidase, chitinase, $\mathrm{N}$-acetyl$\beta$-glucosaminidase, $\alpha$ - and $\beta$-galactosidases, $\alpha$-amylase and $\beta$-glucosidase, $\beta$-fructofuranosidase (or invertase) by Pycnoporus cinnabarinus and in Pycnoporus sanguineus cellulolytic and hemicellulolytic activities, as well as, xylanases, exo-polygalacturonase, PGase I, $\alpha$-Dmannosidase, Avicelase, $\beta$-glucosidase and oxidases mainly laccases were reported (Lomascolo et al. 2011). Eugenio et al. (2009) reported the strong influence of four carbon sources (maltose, glucose, fructose and sucrose) and four nitrogen sources (ammonium tartrate, sodium nitrate, asparagine and yeast extract) on the activity of laccase from Pycnoporus sanguineus.

A mix of sucrose and asparagineinduced the best results $(320 \mathrm{mU} / \mathrm{mL})$, however, with an increase of 5 times the asparagine concentration, laccase activity was increased to $820 \mathrm{mU} / \mathrm{mL}$. Pycnoporus sanguineus produced laccases using a medium containing $200 \mathrm{mg} / \mathrm{L}$ of 2,5 -xylidine or $50 \mathrm{~g} / \mathrm{L}$ of ethanol, the maximum activity was $2019 \mathrm{U} / \mathrm{L}$ and $1035 \mathrm{U} / \mathrm{L}$, respectively. The biomass and laccase activity did not show correlation in any case. Ethanol is a cheaper inducer with little toxic effect for laccase production by Pycnoporus sanguineus (Valeriano et al. 2009). Three anthraquinonic dyes were used to understand their in vivo decolourisation for laccases of Pycnoporus strains. Pycnoporus sanguineus MUCL 41582 (PS7) and Pycnoporus cinnabarinus MUCL39533 (PC330) were used. The first, reported as a producer of laccase and the second, described as laccase-deficient. In medium without dye, laccase activity was observed only by the PS7 strain, however, in the presence of either, Acid Blue 62 (ABu62), Acid Blue 281 (ABu281) and Reactive Blue 19 (RBu19), the laccase activity was also observed with PC330 strain (Vanhulle et al. 2007). Pycnoporus sanguineus is a fungus reported as a biosorbent of metal ions. This process depends on $\mathrm{pH}$, initial metal concentration, temperature and biomass loading. This fungus can be reused multiple times and can be used on an industrial scale (Yahaya \& Don 2014). Pycnoporus sanguineus MUCL 51321 isolated in Gabon was grown in solid and liquid media and showed laccase and manganese peroxidase activities. On the other hand, this fungus was able to discolor at $81 \%$ and $97 \%$ the orange $\mathrm{G}(0.05 \mathrm{~g} / \mathrm{L})$ and reactive blue $4(0.3 \mathrm{~g} / \mathrm{L})$, respectively (Christiane et al. 2013). Pycnoporus sanguineus and Trametes membranacea were evaluated for decolorization of dyes Orange II and Black V. Malt and King media supplemented with $0.05 \%$ dyes, either Orange II and Black $\mathrm{V}$ at $\mathrm{pH} 4.5$ and 5.0 in the presence or absence of agitation and/or luminosity were used. The decolorization was over $50 \%$ for the dyes in all flasks under agitation (Da Paz et al. 2014).

Ganoderma applanatum and Pycnoporus sanguineus from Misiones (Argentina) were grown in dyes and kraft black liquor. Black liquor is a kraft pulping process effluent containing solubilized lignin, the primary organic by product from the chemical digestion of lignocellulosic raw materials. Dye decolorization (bromophenol blue, malachite green) were made in solid culture and black liquor degrading studies were conducted in solid and liquid cultures. These experiments validated the dye and lignin degrading ability of both fungi in solid and liquid cultures (Shimizu et al. 2009). Singh et al. (2012) reported the biodegradation of oil palm biomass and its study for 
pretreatment of laccase activity by Pycnoporus sanguineus. Laccase was produced at room temperature in the presence of Kirk medium supplemented with glucose, ammonium nitrate and corn steep liquor. Laccases resisted temperatures from 10 to $70^{\circ} \mathrm{C}$ and $\mathrm{pH}$ of $2.5-6$. It was observed that the selective degradation of lignin was 4 weeks. Weight and component losses of oil palm trunk chips after decay were evaluated and analyzed by scanning electron microscopy.

The maximum laccase activity was $1.007 \mathrm{U} / \mathrm{L}$ after 10 days of incubation. Pycnoporus sanguineus was grown in bothshake flasks and stirred tank reactors, and Ag nanoparticles were synthesized. The morphology, structure uniformity and concentration of Ag nanoparticles were evaluated by UV-vis spectroscopy, dynamic light scattering, atomic absorption spectroscopy and transmission electron microscopy. Proteins with molecular weight of 37.5-69.6 kDa (SDS-PAGE) were related with biosynthesis of Ag nanoparticles. The yield of Ag nanoparticles in the stirred tank reactor was higher with controllable sizes than those produced in shake flasks studies (San et al. 2013).

\section{Omic technologies and strategies on pycnoporus genus}

Recently developed technologies in genetics and informatics gave the scientific community the tools to study from a holistic point of view, the complexity of biological processes that take place in a cell, tissue or organism as well as the molecules involved in them. These new disciplines can be summarized by the term "Omic" (Horgan \& Kenny 2011). This term first emerged in the field of genomics, and then new disciplines as fields of proteomics, metabolomics, and transcriptomics adopted it. The objective of the omic technologies is the detection of genes (genomics), mRNA (transcriptomics), proteins (proteomics) and metabolites (metabolomics) in a biological sample (Kell 2007). The integration of all these disciplines is now called systems biology (Kitano 2002, Breitling 2010). The basic aspect of these approaches is that a complex system can be understood more thoroughly if considered as a whole, the posterior analysis of the information generated by these strategies could help in the formulation of different hypothesis, contrasting with traditional strategies in which a hypothesis is generated prior to conducting the experiments (Kell \& Oliver 2004).

The omic strategies have many applications and potential. They can be applied not only for the better understanding of physiological processes that take place in a biological sample; they are also useful to understand disease processes (Horgan \& Kenny 2011). These techniques, integrated, could also help to discover new therapeutics and the targets for its action (Ulrich-Merzenich et al. 2007, Ahn \& Wang 2008, Sleno \& Emili 2008, Caberlotto \& Lauria 2015), along with enzymes and other proteins or metabolites of clinical or industrial interest from different sources (Fridman \& Pichersky 2005, Rochfort 2005, Tang \& Zhao 2009, O'Flaherty \& Klaenhammer 2011).

The omic technologies have been applied to the study of different fungi, to study their pathogenicity (Yoder \& Turgeon 2001; Van de Wouw \& Howlett 2011) or for their medical and industrial potential (Keller et al. 2005, Carberry \& Doyle 2007, Gonzalez-Fernandez \& JorrinNovo 2011, Grigoriev et al. 2011). One of the main interests for the application of the omic technologies in fungi, is the identification of powerful enzymes with the potential to breakdown plant biomass for applications in biorefinery (Polizeli et al. 2005, Maciel \& Ribeiro 2010, Kubicek 2012, Ferreira et al. 2013), degrading of pollutants in environmental applications (Wesenberg et al. 2003, Singh \& Singh 2014), or for their use in the food, pharmaceutical and cosmetic industries (Hyde et al. 2010, Tilay et al. 2010, Lopes et al. 2013).

\section{Genomic of Pycnoporus genus}

Among the most important motivations to sequence fungal genomes is to highlight their impact over human well-being especially in medicine, health care, biotechnology, food security, alternative energy, and maintaining the ecological integrity (Robbertse \& Tatusova 2011). The first fungal genome was from Sacharomyces cerevisiae published in 1996 (Goffeau et al. 1996). From this report, many sequencing initiatives to obtain the genomic information from the most representative fungal groups were established, generating the report of many fungal genomes 
(Grigoriev et al. 2014). The analysis of all this information could help to discover new molecules with biotechnological potential.

The first genome from a Pycnoporus genus species was recently published (Levasseur et al. 2014). The white-rot fungus, Pycnoporus cinnabarinus is a model for the study of plant cell wall decomposition and is used for a number of applications in green and white biotechnology. The $33.67 \mathrm{Mb}$ genome of Pycnoporus cinnabarinus BRFM137 was sequenced and assembled, with a $\mathrm{G}+\mathrm{C}$ content of $52.6 \%$ and the presence of 10,442 predicted genes (ORFs). Of this number, 5,417 were functionally annotated using a phylogenomic procedure and grouped in three categories; biological processes, cellular components and molecular function. Among the annotated genes, several enzymes involved in carbohydrate metabolism, lignin degrading and wood decay were identified (Levasseur et al. 2014). The sequencing of the genome of other Pycnoporus genus species as Pycnoporus coccineus strains CIRM1662 and BRFM310, and Pycnoporus sanguineus BRFM1254 are in process, according to the information generated by the "Survey of lignocelloulolytic capabilities over the order Polyporales (Fungi, Basidiomyces)" project deposited in the Joint Genome Institute portal (JGI, 2015) and in the publication of Busk et al. (2014).

\section{Trascriptomic of Pycnoporus genus}

Transcriptomics is the global analysis of gene expression at the RNA level. This technique is important to understand the gene functions and their abundance for a specific developmental stage or physiological condition in the organism under study (Wang et al. 2009). At present transcriptomics is a robust, high-throughput, cost-effective technology capable of simultaneously quantifying tens of thousands of defined mRNA species in a miniaturized, automated format (Hegde et al. 2003). Recently many transcriptomic studies have been performed on fungi. Examples are yeasts such as Candida albicans and C. dubliniensis (Bruno et al. 2010, Grumaz et al. 2013), filamentous fungi such as Aspergillus fumigatus (Gautam et al. 2008), A. nidulans (Sibthorp et al. 2013), Colletotrichum orbiculare (Gan et al. 2012) and Trichoderma spp. (Seidl et al. 2009, Atanasoba et al. 2013), as well basidiomycete fungi such as Coprinopsis cinerea (Cheng et al. 2013), Phanerochaete carnosa (MacDonald et al. 2011), Phanerochaete chrysosporium (Wymelenberg et al. 2009), and Pleurotus ostreatus (Castanera et al. 2012), among others.

The first trancriptomic study on a Pycnoporus genus member was performed by Rohr et al. (2013). In their study the fungus Pycnoporus sanguineus strain BAFC2126 was grown in media supplemented with copper sulfate to favor the transcription of laccases, glyoxal oxidases and manganese peroxidases prior to the trascriptomic analysis. Results of the study show 7,303 transcripts were obtained, of this number 4,732 were assigned by similarity, and identified as 178 potential enzymes with activity over carbohydrates as glycoside hydrolases, glycosyltransferases, carbohydrate esterases and polysaccharide lyases, as well enzymes related to lignocellulose degradation as laccases, multicopper oxidases, lignin peroxidases, manganese peroxidases, and versatile peroxidases, among others. Terpenoid biosynthesis enzymes were also identified. This study has established that Pycnoporus sanguineus has great potential for the production of enzymes that may be applied in many industries. The transcriptomic study of Pycnoporus coccineus strains BRFM310 and CIRM1662 are in process (JGI 2105).

\section{Proteomic of Pycnoporus genus}

Proteomics is the systematic analysis of the proteins expressed in a cell, tissue or whole organism. This omic technology allows the identification and quantification of large number of proteins related to cellular metabolism, changes in the expressed protein patterns during the growth and development of an individual or in response to environmental factors (Chen \& Harmon 2006). Proteomic studies have been performed to identify the proteins presents in the secretions of different fungi, mainly filamentous fungus (Bhadauria et al. 2007). The first fungi proteomic studies were performed by Grinyer et al. $(2004,2005)$ in Trichoderma atroviride and Trichoderma harzianum with the aim to understand the mechanism related to the control of pathogenic fungi by these species. Since then, other proteomic studies related to filamentous fungi have been published 
(Kim et al. 2007, van Passel et al. 2013). Proteomic studies in basidiomycete fungi have been performed first in the model fungi Coprinopsis cinérea (Hoegger et al. 2007) and Phanerochaete chrysosporium (Abbas et al. 2005, Sato et al. 2007).

Further studies in Phanerochaete chrysosporium to determine the enzymes involved in metabolism of benzoic acid (Matsuzaki et al. 2008), Trametes hirsuta grown in different substrates to study the production of laccases (Vasina et al. 2013), Trametes versicolor to evaluate the production of pollutant degrading enzymes (Lebrum et al. 2011) were performed. Antihypertensive peptide production by edible mushrooms such as Agaricus bisporus and Pleurotus cystidiosus have been studied by proteomics (Lau et al. 2012). Secretome studies in Pycnoporus genus species are limited. Only the secretome of Pycnoporus cinnabarinus strain BRFM137 was analyzed in the work of Lavassier et al. (2014). The fungus was grown in different conditions in liquid phase with the presence of combinations of maltose, birchwood, maize bran, and Avicel, as well as, in solidstate fermentation. Findings indicate that in the cultures with maltose-maize and bran-Avicel, in solid-state fermentation, $52 \%$ and $55 \%$ of the proteins in the secretome were carbohydrases, respectively, while in the maltose and birchwood media only 41 and $47 \%$ of the proteins produced were carbohydrases, respectively.

The production of hemicellulolytic and ligninolytic proteins detected in secretomes, showed different distribution patterns depending on growth conditions. Even if the genome of the fungus is available, the identity and function of many of the secreted proteins remains to be elucidated. The proteomic study of the secretome of fungi may lead to the discovery of novelty enzymes and help in the understanding of the strategies and synergistic effects of fungal extracellular biocatalysts (Bouws et al. 2008).

\section{Acknowledgements}

Thanks to The National Council of Science and Technology of Mexico (CONACYT) for supporting scientific stay of Gerardo Díaz Godínez (Application 233234).

\section{References}

Abbas A, Koc H, Liu F, Tien M. 2005 - Fungal degradation of wood: initial proteomic analysis of extracellular proteins of Phanerochaete chrysosporium grown on oak substrate. Current Genetics 47, 49-56.

Achenbach H, Blümm E. 1991 - Investigation of the Pigments of Pycnoporus sanguineus Pycnosanguin and New Phenoxazin-3-ones. Archiv der Pharmazie 324, 3-6.

Acosta-Urdapilleta L. Paz GA, Rodríguez A, Adame M, Salgado D, Salgado J, Montiel-Peña M, Medrano-Vega F, Villarreal ECV. 2010 - Pycnoporus sanguineus un hongo con potencial biotecnológico. In Hacia un desarrollo sostenible del sistema de producción-consumo de los hongos comestibles y medicinales en Latinoamérica: avances y perspectivas en el Siglo XXI. D. Martínez-Carrera, N. Curvetto, M. Sobal, P. Morales, V.M. Mora. Red natinoamericana de hongos comestibles. Pp. 531-537.

Ahn NG, Wang AHJ. 2008 - Proteomics and genomics: Perspectives on drug and target discovery. Current Opinion in Chemical Biology 12, 1-3.

Alves MCRA, Record E, Lomascolo A, Scholtmeijer K, Asther M, Wessels GHJ, Wösten ABH. 2004 - Highly efficient production of laccase by the basidiomycete Pycnoporus cinnabarinus. Applied and Environmental Microbiology 70, 6379-6384.

Aspinall GO, Fanous HK. 1984 - Structural investigations on the non-starchy polysaccharides of apples. Carbohydrate Polymers 4, 193-214.

Bhadauria V, Zhao WS, Wang LX, Zhang Y, Liu JH, Yang J, Kong LA, Peng YL - 2007. Advances in fungal proteomics. Microbiology Research 162, 193-200.

Bobadilla EA, Suirezs TM, Pereyra O, Weber E, Silva F, Stehr AM. 2007 - Durabilidad de la madera del Pinus taeda L. impregnado con arseniato de cobre cromatado, frente a hongos xilófagos, Misiones Argentina. Floresta 37, 15-20. 
Bonnin E, Saulnier L, Brunel M, Marot C, Lesage-Meessen L, Asther M, Thibault JF. 2002 Release of ferulic acid from agroindustrial by-products by the cell wall-degrading enzymes produced by Aspergillus niger I-1472. Enzyme and Microbial Technology 31, 1000-1005.

Borderes J, Costa A, Guedes A, Benathar L, Tavares B. 2011 - Antioxidant activity of the extracts from Pycnoporus sanguineus mycelium. Brazilian Archives of Biology and Technology 54, $1167-1174$.

Bose SR. 1946 - Antibiotics in a Polyporus (Polystictus sanguineus). Nature 158, 292-296.

Bouws H, Wattenberg A, Zorn H. 2008 - Fungal secretomes-nature's toolbox for white biotechnology. Applied Microbiology and Biotechnology 80, 381-388.

Breitling R. 2010 - What is Systems Biology? Frontiers in Physiology 1,9 DOI: 10.3389/fphys.2010.00009

Bruno VM, Wang Z, Marjani SL, Euskirchen GM, Martin J, Sherlock G, Snyder M. 2010 Comprehensive annotation of the transcriptome of the human fungal pathogen Candida albicans using RNA-seq. Genome Research 20, 1451-1458.

Bücker A, Falcão-Bücker NC, de Souza AQL, Gama AM, Rodrigues-Filho E, Costa FMD, Nunez VC, e Silva A.C., and Tadei, W.P. 2013 - Larvicidal effects of endophytic and basidiomycetefungus extracts on Aedes and Anopheles larvae (Diptera, Culicidae). Revista da Sociedade Brasileira de Medicina Tropical 46, 411-419.

Busk PK, Lange M, Pilgaard B, Lange L. 2014 - Several genes encoding enzymes with the same activity are necessary for aerobic fungal degradation of cellulose in Nature. PloS One 9, e114138.

Caberlotto L, Lauria M. 2015 - Systems biology meets-omic technologies: novel approaches to biomarker discovery and companion diagnostic development. Expert Review of Molecular Diagnostics 15, 255-265.

Carberry S, Doyle S. 2007 - Proteomic studies in biomedically and industrially relevant fungi. Cytotechnology 53, 95-100.

Castanera R, Pérez G, Omarini A, Alfaro M, Pisabarro AG, Faraco V, Amore A, Ramírez L. 2012 - Transcriptional and enzymatic profiling of Pleurotus ostreatus laccase genes in submerged and solid-state fermentation cultures. Applied and Environmental Microbiology 78, 4037-4045.

Cavill GWK, Ralph BJ, Tetaz JR, Werner RL. 1953 - The chemistry of mould metabolites. Part I. Isolation and characterization of a red pigment from Coriolus sanguineus (Fr.). Journal of the Chemical Society (Resumed) 525-529.

Chen S, Harmon AC. 2006 - Advances in plant proteomics. Proteomics 6, 5504-5516.

Cheng CK, Au CH, Wilke SK, Stajich JE, Zolan ME, Pukkila PJ, Kwan HS. 2013 - 5'-Serial analysis of gene expression studies reveal a transcriptomic switch during fruiting body development in Coprinopsis cinerea. BMC Genomics 14, 195.

Christiane A, Steeve M, Jean-Bosco ST, Kor NM, Brama I, Eric G, Philippe G. 2013 Biodegradation of reactive blue 4 and orange $\mathrm{G}$ by Pycnoporus sanguineus strain isolated in Gabon. Journal of Bioremediation \& Biodegradation 4, 206.

Cifuentes J, Villegas M, Perez-Ramirez L. 1986 - Hongos. In Manual de Herbario. A. Lot and F. Chiang.Consejo Nacional de la Flora, Mexico D.F.

Correa E, Cardon D, Quiñones W, Torres F, Franco AE, Vélez ID, Robledo S, Echeverri F. 2006 Leishmanicidal activity of Pycnoporus sanguineus. Phytotherapy Research 20, 497-499.

Correa E, Quiñones W, Torres F, Cardona D, Franco AE, Robledo S, Echeverri F. 2005 Actividad leishmanicida de Pycnoporus sanguineus. Actual Biol 27, 39-42.

Crozier J, Thomas SE, Aime MC, Evans HC, Holmes KA. 2006 - Molecular characterization of fungal endophytic morphospecies isolated from stems and pods of Theobroma cacao. Plant Pathology 55, 783-791.

Da Paz ESL, Júnior FP, Neto BB, Cavalcanti MAQ. 2014 - Decolorization of azo dyes by Pycnoporus sanguineus and Trametes membranacea. African Journal of Biotechnology 11, 8391-8397. 
Dantán-González E, Vite-Vallejo O, Martínez-Anaya C, Méndez-Sánchez M, González MC, Palomares LA, Folch-Mallol J. 2008 - Production of two novel laccase isoforms by a thermotolerant strain of Pycnoporus sanguineus isolated from an oil-polluted tropical habitat. International Microbiology 11, 163-169.

de Oliveira LF, Le Hyaric M, Berg MM, de Almeida MV, Edwards HG. 2007 - Raman spectroscopic characterization of cinnabarin produced by the fungus Pycnoporus sanguineus (Fr.) Murr. Journal of Raman Spectroscopy 38, 1628-1632.

Deacon JW. 2013 - Fungal Biology.Wiley-Blackwell.

Dias DA, Urban S. 2009 - HPLC and NMR studies of phenoxazone alkaloids from Pycnoporus cinnabarinus. Natural product communications 4, 489-498.

Díaz-Barriga H, Guevara F, Valenzuela R. 1988 - Contribución al conocimiento de los macromicetos del estado de Michoacán. Acta Botánica Mexicana 2, 21-44.

Dupont J, Laloui W, Roquebert MF. 1998 - Partial ribosomal DNA sequences show an important divergence between Phaeoacremonium species isolated from Vitis vinifera. Mycological Research 5, 631-637.

Eggert C, Temp U, Dean JFD, Eriksson KEL. 1995 - Laccase-mediated formation of the phenoxazinone derivative, cinnabarinic acid. FEBS Letters 376, 202-206.

Eggert C, Temp U, Eriksson KE. 1996 - The ligninolytic system of the white rot fungus Pycnoporus cinnabarinus: purification and characterization of the laccase. Applied and Environmental Microbiology 62, 1151-1158.

Eggert C. 1997 - Laccase-catalyzed formation of cinnabarinic acid is responsible for antibacterial activity of Pycnoporus cinnabarinus. Microbiological Research 152, 315-318.

Estrada Alvarado I, Navarro D, Record E, Asther M, Asther M, Lesage-Meessen L. 2003. - Fungal biotransformation of $p$-coumaric acid into caffeic acid by Pycnoporus cinnabarinus: an alternative for producing a strong natural antioxidant. World Journal of Microbiology and Biotechenology 19, 157-160.

Eugenio ME, Carbajo JM, Martín JA, González AE, Villar JC. 2009 - Laccase production by Pycnoporus sanguineus under different culture conditions. Journal of Basic Microbiology 49, 433-440.

Fahlbusch KG, Hammerschmidt FJ, Panten J, Pickenhagen W, Schatkowski D, Bauer K, Garbe D, Surburg H. 2003 - Flavors and Fragrances.Ullmann's Encyclopedia of Industrial Chemistry, Wiley-VCH.

Fajana OB, Alofe FV, Onawunmi GO, Ogundaini AO, Olugbade TA. 1999 - Antimicrobial studies on Nigerian higher fungi. Nigerian Journal of Natural Products and Medicine 3, 64-65.

Falconnier, B., Lapierre, C., Lesage-Meessen, L., Yonnet, G., Brunerie, P., Colonna-Ceccaldi, B., and Asther, M. 1994 - Vanillin as a product of ferulic acid biotransformation by the whiterot fungus Pycnoporus cinnabarinus I-937: identification of metabolic pathways. Journal of Biotechnology 37, 123-132.

Fazio F, Lionetto L, Molinaro G, Bertrand HO, Acher F, Ngomba RT, Goudet C. 2012. Cinnabarinic acid, an endogenous metabolite of the kynurenine pathway, activates type 4 metabotropic glutamate receptors. Molecular Pharmacology 81, 643-656.

Ferreira JA, Lennartsson PR, Edebo L, Taherzadeh MJ. 2013 - Zygomycetes-based biorefinery: Present status and future prospects. Bioresource Technology 135, 523-532.

Figueroa-Espinoza MC, Rouau X. 1998 - Oxidative cross-linking of pentosans by a fungal laccase and horseradish peroxidase: mechanism of linkage between feruloylated arabinoxylans. Cereal Chemistry 75, 259-265.

Fonseca MI, Zapata PD, Villalba LL, Fariña JI. 2015 - Characterization of the oxidative enzyme potential in wild white rot fungi from misiones (Argentina). Acta Biológica Colombiana 20, 47-56.

Forte S, Polak J, Valensin D, Taddei M, Basosi R, Vanhulle S, Jarosz-Wilkolazka A, Pogni R. 2010 - Synthesis and structural characterization of a novel phenoxazinone dye by use of a fungal laccase. Journal of Molecular Catalysis B: Enzymatic 63, 116-120. 
Fridman E, Pichersky E. 2005 - Metabolomics, genomics, proteomics, and the identification of enzymes and their substrates and products. Current Opinion in Plant Biology 8, 242-248.

Froslev TG, Matheny PB, Hibbett DS. 2005 - Lower level relationships in the mushroom genus Cortinarius (Basidiomycota, Agaricales): a comparison of RPB1, RPB2, and ITS phylogenies. Molecular Phylogenetics and Evolution 37, 602-618.

Gan P, Ikeda K, Irieda H, Narusaka M, O'Connell RJ, Narusaka Y, Takano Y, Kubo Y, Shirasu K. 2013 - Comparative genomic and transcriptomic analyses reveal the hemibiotrophic stage shift of Colletotrichum fungi. New Phytologist 197, 1236-1249.

Garcia TA, Santiago MF, Ulhoa CJ. 2007 - Studies on the Pycnoporus sanguineus CCT-4518 laccase purified by hydrophobic interaction chromatography. Applied Microbiology and Biotechnology 75, 311-318.

Gautam P, Shankar J, Madan T, Sirdeshmukh R, Sundaram CS, Gade WN, Basir SF, Sarma PU. 2008 - Proteomic and transcriptomic analysis of Aspergillus fumigatus on exposure to amphotericin B. Antimicrobial Agents and Chemotherapy 52, 4220-4227.

Gilbertson RL, Ryvarden L. 1986 - North American Polypores.Vol.I Fungiflora. Oslo, Norway.

Gioia L, Manta C, Ovsejevi K, Burgueño J, Menéndez P, Rodriguez-Couto S. 2014 - Enhancing laccase production by a newly-isolated strain of Pycnoporus sanguineus with high potential for dye decolouration. RSC Advances 4, 34096-34103.

Göçenoğlu A, Pazarlioglu N. 2014 - Cinnabarinic acid: Enhanced production from Pycnoporus cinnabarinus, characterization, structural and functionalproperties. The Journal of Biological Chemistry 42, 281-290.

Goffeau A, Barrell BG, Bussey H, Davis RW, Dujon B, Feldmann H, Galibert F, Hoheisel JD, Jacq C, Johnston M, Louis EJ, Mewes HW, Murakami Y, Philippsen P, Tettelin H, Oliver SG. 1996 - Life with 6000 genes. Science 274, 546-567.

Gómez-Toribio V, García-Martín AB, Martínez MJ, Martínez ÁT, Guillén F. 2009 - Induction of extracellular hydroxyl radical production by white-rot fungi through quinone redox cycling. Applied and Environmental Microbiology 75, 3944-3953.

Gonzalez-Fernandez R, Jorrin-Novo JV. 2011 - Contribution of proteomics to the study of plant pathogenic fungi. Journal of Proteome Research 11,3-16.

Grigoriev IV, Cullen D, Goodwin SB, Hibbett D, Jeffries TW, Kubicek CP, Kuske C, Magnuson JK, Martin F, Spatafora JW, Tsang A, Baker SE. 2011 - Fueling the future with fungal genomics. Mycology 2, 192-209.

Grigoriev IV, Nikitin R, Haridas S, Kuo A, Ohm R, Otillar R, Riley R, Salamov A, Zhao X, Korzeniewski F, Smirnova T, Nordberg H, Dubchak I, Shabalov I. 2014 - MycoCosm portal: gearing up for 1000 fungal genomes. Nucleic Acids Research 42, D699-704.

Grinyer J, Hunt S, McKay M, Herbert BR, Nevalainen H. 2005 - Proteomic response of the biological control fungus Trichoderma atroviride to growth on the cell walls of Rhizoctonia solani. Current Genetics 47, 381-388.

Grinyer J, McKay M, Nevalainen H, Herbert BR. 2004 - Fungal proteomics: initial mapping of biological control strain Trichoderma harzianum. Current Genetics 45(3), 163-169.

Gripenberg J. 1951 - Fungus Pigments I. Cinnabarin a colouring matter from Trametes cinnabarina Jacq. Acta Chemica Scandinavica 5, 590-595.

Gripenberg J. 1958 - Fungus pigments. IX. Some further constituents of Hydnum aurantiacum Batsch. Acta Chemica Scandinavica 12, 1411-1414.

Gripenberg J. 1963 - Fungus pigments. XIII: Tramesanguin, the pigment of Trametes cinnabarina var. sanguinea (L.) Pilat. Acta Chemica Scandinavica 17, 703-708.

Gross B, Asther M, Corrieu G, Brunerie P. 1991 - Production de vanilline par bioconversion de precurseurs benzeniques. European Patent No. 0453368Al. https://www.google.com.mx/patents/EP0453368B1?cl=en\&dq=patents/EP0453368A1\&hl= es\&sa=X\&ei=FdLrVLTsCpWAygSwg4LgCQ\&ved=0CBsQ6AEwAA. 
Gross B, Yonnet G, Picque D, Brunerie P, Corrieu G, Asther M. 1990 - Production of methylanthranilate by the basidiomycete Pycnoporus cinnabarinus (Karst.). Applied Microbiology and Biotechnology 34, 387-391.

Grumaz C, Lorenz S, Stevens P, Lindemann E, Schöck U, Retey J, Rupp F, Sohn K. 2013 Species and condition specific adaptation of the transcriptional landscapes in Candida albicans and Candida dubliniensis. BMC Genomics 14, 212.

Guarro J, Gené J, Stchigel AM. - 1999. Developments in Fungal Taxonomy. Clinical Microbiology Reviews 12, 454-500.

Guzmán G. 1979 - Identificación de los hongos comestibles, venenosos, alucinantes, y destructores de la madera. Editorial Limusa, México.

Guzmán G. 2003 - Hongos de El Edén Quintana Roo. Introducción a la micobiota tropical de México. INECOL y CONABIO, Xalapa.

Halaouli S, Asther M, Kruus K, Guo L, Hamdi M, Sigoillot JC, Asther M, Lomascolo A. 2005 Characterization of a new tyrosinase from Pycnoporus species with high potential for food technological applications. Journal of Applied Microbiology 98, 332-343.

Hatsch D, Phalip V, Jeltsch JM. 2004 - Use of genes encoding cellobiohydrolase-C and topoisomerase II as targets for phylogenetic analysis and identification of Fusarium. Research in Microbiology 155, 290-296.

Hayashi T, Rao SP, Takabayashi K, Van Uden JH, Kornbluth RS, Baird SM, Taylor MW, Carson DA, Catanzaro A, Raz E. 2001 - Enhancement of innate immunity against Mycobacterium avium Infection by immunostimulatory DNA is mediated by indoleamine 2, 3-Dioxygenase. Infection and Immunity 69, 6156-6164.

Hegde PS, White IR, Debouck C. 2003 - Interplay of transcriptomics and proteomics. Current Opinion in Biotechnology 14, 647-651.

Herpoël I, Jeller H, Fang G, Petit-Conil M, Bourbonnais R, Robert JL, Asther M, Sigoillot JC. 2002 - Efficient enzymatic delignification of wheat straw pulp by a sequential xylanase-laccase treatment. Journal of Pulp and Paper Science 28, 67-71.

Herpoël I, Moukha S, Lesage-Meessen L, Sigoillot C, Asther M. 2000 - Selection of Pycnoporus cinnabarinus strains for laccase production. FEMS Microbiology Letters 183, 301-306.

Hibbett DS, Binder M, Bischoff JF, Blackwell M, Cannon PF, Eriksson OE, Reeb V. 2007 - A higher-level phylogenetic classification of the fungi. Mycological Research 111, 509-547.

Hoegger PJ, Majcherczyk A, Dwivedi RC, Svobodová K, Kilaru S, Kües U. 2007 - Enzymes in Wood Degradation. In Wood Production, Wood Technology, and Biotechnological Impacts. U. Kues. Universitatsverlag Gottingen. Pp. 383-419.

Hood IA. 2006 - The mycology of the Basidiomycetes. In Heart rot and root rot in tropical Acacia plantations. Proceedings of a workshop held in Yogyakarta, Indonesia. K. Potter, A. Rimbawanto and C. Beadle.Canberra, ACIAR Proceedings 124.

Horgan RP, Kenny LC. 2011 - 'Omic' technologies: genomics, transcriptomics, proteomics and metabolomics. The Obstetrician \& Gynaecologist 13, 189-195.

Hyde KD, Bahkali AH, Moslem MA. 2010 - Fungi an unusual source for cosmetics. Fungal Diversity 43, 1-9.

Imtiaj A, Jayasinghe C, Lee GW, Lee TS. 2007 - Antibacterial and antifungal activities of Stereum ostrea an inedible wild mushroom. Mycobiology 35, 210-214.

Jiang MY, Feng T, Liu JK. 2011 - N-Containing compounds of macromycetes. Natural Product Reports 28, 783-808.

Kell DB, Oliver SG. 2004 - Here is the evidence, now what is the hypothesis? The complementary roles of inductive and hypothesis-driven science in the post-genomic era. BioEssays 26, 99105.

Kell DB. 2007 - The virtual human: towards a global systems biology of multiscale, distributed biochemical network models. IUBMB Life 59, 689-695.

Keller NP, Turner G, Bennett JW. 2005 - Fungal secondary metabolism-from biochemistry to genomics. Nature Reviews Microbiology 3, 937-947. 
Kim Y, Nandakumar MP, Marten MR. 2007 - Proteomics of filamentous fungi. TRENDS Biotechnology 25, 395-400.

Kitano H. 2002 - Systems biology: a brief overview. Science 295, 1662-1664.

Kuang LM, Lin HO, Hsu FL, Lin YL. 2010 - Anti-inflammatory principles of cultivated Pycnoporus sanguineus. Journal Chinese Medical 21, 75-83.

Kubicek CP. 2012 - Lignocellulose biorefinery. In Fungi and lignocellulosic biomas. C.P.Kubicek. Oxford, UK: Wiley-Blackwell.

Kuhad RC, Singh A, Eriksson KEL. 1997 - Microorganisms and enzymes involved in the degradation of plant fiber cell walls. Advances in Biochemical Engineering/Biotechnology $57,45-125$.

Larena I, Salazar O, Gonzalez V, Julian M, Rubio V. 1999 - Design of a primer for ribosomal DNA internal transcribed spacer with enhanced specificity for ascomycetes. Journal of Biotechnology 75, 187-194.

Lau CC, Abdullah N, Shuib AS, Aminudin N. 2012 - Proteomic analysis of antihypertensive proteins in edible mushrooms. Journal of Agricultural and Food Chemistry 60, 1234112348.

Le Roes-Hill M, Goodwin C, Burton S. 2009 - Phenoxazinone synthase: what's in a name?. Trends in Biotechnology 27, 248-258.

Leonowicz A, Cho N, Luterek J, Wilkolazka A, Wojtas-Wasilewska M, Matuszewska A, Rogalski J. 2001 - Fungal laccase: properties and activity on lignin. Journal of Basic Microbiology 41, 185-227.

Lesage-Meessen L, Haon M, Uzan E, Levasseur A, Piumi F, Navarro D, Taussac S, Favel A, Lomascolo A. 2011 - Phylogeographic relationships in the polypore fungus Pycnoporus inferred from molecular data. FEMS Microbiology Letters 325, 37-48.

Levasseur A, Lomascolo A, Chabrol O, Ruiz-Dueñas FJ, Boukhris-Uzan E, Piumi F, Kües U, Ram AFJ, Murat C. 2014 - The genome of the white-rot fungus Pycnoporus cinnabarinus: a basidiomycete model with a versatile arsenal for lignocellulosic biomass breakdown. BMC Genomics 15, 486.

Lomascolo A, Cayol JL, Roche M, Guo L, Robert JL, Record E, Lesage-Meessen L, Ollivier B, Sigoillot JC, Asther M. 2002 - Molecular clustering of Pycnoporus strains from various geographic origins and isolation of monokaryotic strains for laccase hyperproduction. Mycological Research 106, 1193-1203.

Lomascolo A, Stentelaire C, Asther M, Lesage-Meessen L. 1999 - Basidiomycetes as new biotechnological tools to generate natural aromatic flavours for the food industry. Trends in Biotechnology 17, 282-289.

Lomascolo A, Uzan-Boukhris E, Herpoël-Gimbert I, Sigoillot JC, Lesage-Meessen L. 2011 Peculiarities of Pycnoporus species for applications in biotechnology. Applied Microbiology and Biotechnology 92, 1129-1149.

Lopes FC, Tichota DM, Pereira JQ, Segalin J, de Oliveira Rios A, Brandelli A. 2013 - Pigment production by filamentous fungi on agro-industrial byproducts: an eco-friendly alternative. Applied Biochemistry and Biotechnology 171, 616-625.

MacDonald J, Doering M, Canam T, Gong Y, Guttman DS, Campbell MM, Master ER. 2011 Transcriptomic responses of the softwood-degrading white-rot fungus Phanerochaete carnosa during growth on coniferous and deciduous wood. Applied and Environmental Microbiology 77, 3211-3218.

Maciel MJM, Ribeiro HCT. 2010 - Industrial and biotechnological applications of ligninolytic enzymes of the basidiomycota: A review. Electronic Journal of Biotechnology 13, 14-15.

Matsuzaki F, Shimizu M, Wariishi H. 2008 - Proteomic and metabolomic analyses of the white-rot fungus Phanerochaete chrysosporium exposed to exogenous benzoic acid. Journal of Proteome Research 7, 2342-2350.

Nair PM, Vining LC. 1964 - An isophenoxazine synthase from Pycnoporus coccineus (Fr.) Bond.and Sing. Canadian Journal Biochemical 42, 1515-1526. 
Nilsson RH, Kristiansson E, Ryberg M, Hallenberg N, Larsson KH. 2008 - Intraspecific ITS variability in the kingdom Fungi as expressed in the international sequence databases and its implications for molecular species identification. Evolutionary Bioinformatics Online 4, 193-201.

Nobles MK, Frew BP. 1962 - Studies in wood-inhabiting hymenomycetes: V. The genus Pycnoporus Karst. Canadian Journal of Botany 40, 987-1016.

O'Flaherty S, Klaenhammer TR. 2011 - The impact of omic technologies on the study of food microbes. Annual Review of Food Science and Technology 2, 353-371.

Osiadacz J, Al-Adhami AJH, Bojraszewska D, Fischer P, Peczynska-Czoch W. 1999 - On the use of Trametes versicolor laccase for the conversion of 4-methyl-3-hydroxyanthranilic acid to actinocin chromophore. Journal of Biotechnology 72, 141-149.

Pérez J, Munoz-Dorado J, de la Rubia TDLR, Martinez J. 2002 - Biodegradation and biological treatments of cellulose, hemicellulose and lignin: an overview. International Microbiology $5,53-63$.

Polak J, Jarosz-Wilkołazka A. 2010 - Research whole-cell fungal transformation of precursors into dyes. Microbial Cell Factories 9, 51.

Polizeli MLTM, Rizzatti ACS, Monti R, Terenzi HF, Jorge JA, Amorim DS. 2005 - Xylanases from fungi: properties and industrial applications. Applied Microbiology and Biotechnology 67, 577-591.

Pompa A, Aguirre E, Encalada AV, de Anda A, Cifuentes J, Valenzuela R. 2011 - Los macromicetos del Jardín Botánico de ECOSUR "Dr. Alfredo Barrera Marín" Puerto Morelos. Quintana Roo. CONABIO.

Rabinovich GA, Toscano MA, Ilarregui JM, Rubinstein N. 2002 - Shedding light on the immunomodulatory properties of galectins: novel regulators of innate and adaptive immune responses. Glycoconjugate Journal 19, 565-573.

Robbertse B, Tatusova T. 2011 - Fungal genome resources at NCBI. Mycology 2, 142-160.

Rochfort S. 2005 - Metabolomics reviewed: a new "omics" platform technology for systems biology and implications for natural products research. Journal of Natural Products 68, $1813-1820$.

Rohr CO, Levin LN, Mentaberry AN, Wirth SA. 2013 - A First Insight into Pycnoporus sanguineus BAFC 2126 Transcriptome. PloS One 8(12), e81033. DOI: 10.1371/journal.pone.0081033.

Rosa LH, Machado KMG, Jacob CC, Capelari M, Rosa CA, Zani CL. 2003 - Screening of Brazilian basidiomycetes for antimicrobial activity. Memórias do Instituto Oswaldo Cruz 98, 967-974.

Rungjindamai N, Pinruan U, Choeyklin R, Hattori T, Jones EBG. 2008 - Molecular characterization of basidiomycetous endophytes isolated from leaves, rachis and petioles of the oil palm, Elaeis guineensis. Thailand. Fungal Diversity 33, 139-161.

Ryvarden L, Johansen I. 1980 - A preliminary polypore flora of East Africa. Synopsis fungorum 5. Fungiflora, Oslo.

Ryvarden L, Johansen I. 1980 - A preliminary polypores flore of East Africa. Fungiflora, Oslo.

Ryvarden L. 1978 - The polyporacea of North Europa Vol. II Inonotus-Tyromyces. Oslo.

Ryvarden L. 1991 - Genera of polypores: nomenclature and taxonomy. Oslo. Norway. Synopsis Fungorum 5, 1-363.

San CY, Don MM, Kang LJ, Mohamed AR. 2013 - Comparative studies on the synthesis of silver nanoparticles by Pycnoporus sanguineus in shake flasks and stirred tank reactor. In Chemeca 41st Brisbane, Qld. Challenging Tomorrow. Barton, ACT: Engineers Australia. pp 39-43.

Sato S, Liu F, Koc H, Tien M. 2007 - Expression analysis of extracellular proteins from Phanerochaete chrysosporium grown on different liquid and solid substrates. Microbiology 153, 3023-3033. 
Schliephake K, Mainwaring DE, Lonergan GT, Jones IK, Baker WL. 2000 - Transformation and degradation of the disazo dye Chicago Sky Blue by a purified laccase from Pycnoporus cinnabarinus. Enzyme and Microbial Biotechnology 27, 100-107.

Seidl V, Song L, Lindquist E, Gruber S, Koptchinskiy A, Zeilinger S, Schmoll M, Martínez P, Sun J, Grigoriev I, Herrera-Estrella A, Baker SE, Kubicek CP. 2009 - Transcriptomic response of the mycoparasitic fungus Trichoderma atroviride to the presence of a fungal prey. BMC Genomics 10, 567.

Shimizu E, Velez-Rueda JO, Zapata PD, Villalba LL. 2009 - Relación entre degradación de colorantes y oxidación de lignina residual causados por Ganoderma applanatum y Pycnoporus sanguineus en el licor negro kraft. Revista de Ciencia y Tecnología 12, 46-51.

Shin H, Guebitz G, Cavaco-Paulo A. 2001 - "In situ" enzymatically prepared polymers for wool coloration. Macromolecular Materials and Engineering 286, 691-694.

Shittu OB, Alofe FV, Onawunmi GO, Ogundaini AO, Tiwalade TA. 2006 - Mycelial growth and antibacterial metabolite production by wild mushrooms. African Journal of Biomedical Research 8, 157-162.

Sibthorp C, Wu H, Cowley G, Wong PW, Palaima P, Morozov IY, Weedall GD, Caddick MX. 2013 - Transcriptome analysis of the filamentous fungus Aspergillus nidulans directed to the global identification of promoters. BMC Genomics 14, 847.

Singh AP, Singh T. 2014 - Biotechnological applications of wood-rotting fungi: A review. Biomass and Bioenergy 62, 198-206.

Singh P, Sulaiman O, Hashim R, Peng LC, Singh RP. 2012 - Biodegradation study of Pycnoporus sanguineus and its effects on structural and chemical features on oil palm biomass chips. Lignocellulose 1, 210-227.

Sleno L, Emili A. 2008 - Proteomic methods for drug target discovery. Current Opinion in Chemical Biology 12, 46-54.

Smânia A, Dellemonache F, Smânia EFA, Gil ML, Benchetrit LC, Cruz FS. 1995 - Antibacterial activity of a substance produced by the fungus, Pycnoporus sanguineus (Fr.) Murr. Journal of Ethnopharmacology 45, 177-181.

Smânia A, Marques CJS, Smânia EFA, Zanetti CR, Carobrez SG, Tramonte R, Loguercio-Leite C. 2003 - Toxicity and antiviral activity of cinnabarin obtainedfrom Pycnoporus sanguineus (Fr.) Murr. Phytotherapy Research 17, 1069-1072.

Smânia EF, Smaünia A, Loguercio-Leite C. 1997 - Optimal parameters for cinnabarin synthesis by Pycnoporus sanguineus. Journal of Chemical Technology \& Biotechnology 70, 57-59.

Stentelaire C, Lesage-Meessen L, Oddou J, Bernard O, Bastin G, Ceccaldi BC, Asther M. 2000 Design of a fungal bioprocess for vanillin production from vanillic acid at scalable level by Pycnoporus cinnabarinus. Journal of Bioscience and Bioengineering 89, 223-230.

Suay I, Arenal F, Asensio JF, Basilio A, Cabello MA, Díez MT, García JB, González del Val A, Gorrochategui J, Hernández P, Peláez F, Vicente MF. 2000 - Screening of basidiomycetes for antimicrobial activities. Antonie van Leeuwenhoek 78, 129-139.

Sullivan G, Henry ED. 1971 - Occurrence and distribution of phenoxazinone pigments in the genus Pycnoporus. Journal of Pharmaceutical Sciences 60, 1097-1098.

Tang WL, Zhao H. 2009 - Industrial biotechnology: Tools and applications. Biotechnology Journal 14, 1725-1739.

Teoh YP, Don MM, Ujang S. 2011 - Media selection for mycelia growth, antifungal activity against wood-degrading fungi, and GC-MS study by Pycnoporus sanguineus. Bioresources 6, 2719-2731.

Thongkred P, Lotrakul P, Prasongsuk S, Imai T, Punnapayak H. 2011 - Oxidation of polycyclic aromatic hydrocarbons by a tropical isolate of Pycnoporus coccineus and its laccase. ScienceAsia 37, 225-233.

Tilay A, Bule M, Annapure U. 2010 - Production of biovanillin by one-step biotransformation using fungus Pycnoporous cinnabarinus. Journal of Agricultural and Food Chemistry 58, 4401-4405. 
Tomšovský M, Kolaří M, Pažoutová S, Homolka L. 2006 - Molecular phylogeny of European Trametes (Basidiomycetes, Polyporales) species based on LSU and ITS (nrDNA) sequences. Nova Hedwigia 82, 269-280.

Turner WB. 1971 - Secondary metabolites derived from amino acids. In: Fungal metabolites. WB. Turner. Academic Press London, pp 310-331.

Ulloa M, Hanlin RT. 2006 - Nuevo diccionario ilustrado de micología. The American Pytopathological Society (APS) Prees. St. Paul, Minnesota USA.

Ulrich-Merzenich G, Zeitler H, Jobst D, Panek D, Vetter H, Wagner H. 2007 - Application of the "Omic" technologies in phytomedicine. Phytomedicine 14, 70-82.

Uzan E, Nousiainen P, Balland V, Sipila J, Piumi F, Navarro D, Asther M, Record E, Lomascolo A. 2010 - High redox potential laccases from the ligninolytic fungi Pycnoporus coccineus and Pycnoporus sanguineus suitable for white biotechnology: from gene cloning to enzyme characterization and applications. Journal Applied of Microbiology 108, 2199-2213.

Valenzuela GR. 1999 - Las familias Polyporaceae sensu stricto y Albatrellaceae en México. Instituto Politécnico Nacional. Escuela Nacional de Ciencias Biológicas. Informe final SNIB-CONABIO. México, D.F.

Valeriano SV, Silva AMF, Santiago MF, Bara MTF, Garcia TA. 2009 - Production of laccase by Pycnoporus sanguineus using 2,5 - xylidine and ethanol. Brazilian Journal of Microbiology 40, 790-794.

Van de Wouw AP, Howlett BJ. 2011 - Fungal pathogenicity genes in the age of 'omics'. Molecular Plant Pathology 12, 507-514.

Van Passel MW, Schaap PJ, de Graaff LH. 2013 - Proteomics of filamentous fungi. In Proteomics in Foods. F. Toldra and L.M.L. Nollet.Springer US. Pp. 563-578.

Vanhulle S, Enaud E, Trovaslet M, Nouaimeh N, Bols CM, Keshavarz T, Tron T, Sannia G, Corbisier AM. 2007 - Overlap of laccases/cellobiose dehydrogenase activities during the decolourisation of anthraquinonic dyes with close chemical structures by Pycnoporus strains. Enzyme and Microbial Technology 40, 1723-1731.

Vasina DV, Loginov DS, Koroleva OV. 2013 - Comparative proteomic study of the basidiomycete Trametes hirsuta grown on different substrates. Biochemistry (Moscow) 78, 477-484.

Wang Z, Binder M, Dai YC, Hibbett DS. 2004 - Phylogenetic relationships of sparassis inferred from nuclear and mitochondrial DNA and RNA polymerase sequences. Mycologia 96, 1015-1029.

Wang Z, Gerstein M, Snyder M. 2009 - RNA-Seq: a revolutionary tool for transcriptomics. Nature Reviews Genetics 10, 57-63.

Wesenberg D, Kyriakides I, Agathos SN. 2003 - White-rot fungi and their enzymes for the treatment of industrial dye effluents. Biotechnology Advances 22, 161-187.

White TJ, Bruns T, Lee S, Taylor J. 1990 - Amplification and direct sequencing of fungal ribosomal RNA genes for phylogenetics. In PCR Protocols: a guide to methods and applications. M. A. Innis, D. H. Gelfand, J. J. Sninsky and T. J. White. Academic Press, San Diego. Pp. 315-322.

www.indexfungorum.org.

Wymelenberg AV, Gaskell J, Mozuch M, Kersten P, Sabat G, Martinez D, Cullen D. 2009 Transcriptome and secretome analyses of Phanerochaete chrysosporium reveal complex patterns of gene expression. Applied and Environmental Microbiology 75, 4058-4068.

Yahaya YA, Don MM. 2014 - Pycnoporus sanguineus as potential biosorbent for heavy metal removal from aqueous solution: A Review. Journal of Physical Science 25, 1-32.

Yoder OC, Turgeon BG. 2001 - Fungal genomics and pathogenicity. Current Opinion in Plant Biology 4, 315-321.

Zulfadhly Z, Mashitah, MD, Bhatia S. 2001 - Heavy metals removal in fixed-bed column by the macro fungus Pycnoporus sanguineus. Environmental Pollution 112, 463-470. 